\title{
Automation fears: drivers and solutions
}

\author{
Stanislav Ivanov \\ Professor, Varna University of Management, 13A Oborishte Str., 9000 Varna, Bulgaria, tel: \\ +35952 300 680, e-mail: stanislav.ivanov@ vumk.eu . Personal website: \\ http://www.stanislavivanov.com
}

\section{Mihail Kuyumdzhiev}

Design engineer, IDT Bulgaria ltd, 24 Slivnitsa Blvd., 9000 Varna, Bulgaria, tel: +359 888268 910, e-mail: kuyumdzhiev.mihail@gmail.com

\section{Craig Webster}

Associate Professor, Department of Management, Miller College of Business, Ball State University, Muncie, Indiana, USA, e-mail: cwebster3@bsu.edu

\begin{abstract}
:
New technologies offer employers the ability to replace tasks done by human labour with those done by machines. There are challenges for both employers and employees, as employers look for strategies for the implementation of automation technologies and employees may have concerns about their employment being threatened by automation technologies. In this research, we analyse data of over 500 Bulgarians to learn about how they perceive the automation of their job. The analysis finds that there are segments of the population defined by demographics and attitudes that are more fearful of the automation of their jobs than others. Additionally, we see that attitudes towards the dehumanizing effects of automation, peer-pressure, job automatability, and a person's self-perception of professionalism are the main drivers of the fear of automation. Finally, the paper evaluates respondents' attitudes towards various individual, corporate and social solution to automation fears.
\end{abstract}

Key words: automation fear, workplace automation, robots, solutions to automation fears, future of work 


\section{Highlights:}

- The paper discusses the fear of automation

- The sample includes 502 respondents from Bulgaria

- Dehumanizing effects of automation, peer-pressure, job automatability, and professionalism are the drivers of automation fears

- Respondents support mostly individual solutions, followed by corporate and social solutions

Citation: Ivanov, S., Kuyumdzhiev, M., \& Webster, C. (2020). Automation fears: drivers and solutions. Technology in Society (in press). 


\section{Automation fears: drivers and solutions}

\section{Introduction}

\subsection{Rationale}

Automation technologies (ATs) include a wide range of technologies such as industrial robots (Cubero, 2007; Miller \& Miller, 2017; Ross, Fardo \& Walach, 2018), service and social robots (Bhaumik, 2018; Nørskov, 2016), artificial intelligence (Ertel, 2017; Neapolitan \& Jiang, 2018; Russell \& Norvig, 2016), vending machines, ATMs, kiosks, chatbots (Singh, Ramasubramanian, \& Shivam, 2019), automated trading algorithms (Chan, 2017), and other technologies that allow the production and sale of goods and services with no or minimum human involvement. The technological progress over the last decades has increased the capabilities of ATs and decreased their prices leading to their implementation in various industries (Bhatnagar, 2020; Delgado et al., 2019; Kabugo et al., 2020; Moutsatsou et al., 2019), including agriculture (Driessen \& Heutinck, 2015; Slaughter, Giles \& Downey, 2008) and services (Huang \& Rust, 2018; Ivanov \& Webster, 2019a; Wirtz et al., 2018). Automation technologies are used as autonomous vehicles for transporting goods and people (Maurer et al., 2016), in warehousing and supply chain management (Wurman, D’Andrea \& Mountz, 2008), in communicating and maintaining relationships with customers through chatbots (Buhalis \& Yen, 2020; Hill, Ford \& Farreras, 2015), for automated pricing decisions (Tonkova, 2016), for facial recognition and automated border control (del Rio et al., 2016), for provision of legal services (Remus \& Levy, 2015), for trading on financial markets (Dunis et al., 2017), and for countless other applications. Driven by their search for greater productivity, competitiveness, profitability, and lower dependency on scarce human talent, companies invest heavily in ATs and replace some of their employees. The International Federation of Robotics (2019) reports that in 2018 alone, the number of newly installed industrial robots was 422,271 to reach a total of 2,439,543 operating industrial robots. There are even instances of American robots losing their jobs to Asian robots (New York Post, 2019).

Every automation technology has both enhancement and substitution effects simultaneously (Decker, Fischer \& Ott, 2017; Frey, 2019; Ivanov \& Webster, 2019b). The enhancement effect means that the adoption of a new technology allows the employees to perform better at their jobs and increase their productivity. Through the substitution effect the new technology replaces the human workers who were previously doing the same tasks. The massive implementation of automation technologies changes the nature of work human employees 
perform (Ernst, Merola, \& Samaan, 2019; Webster \& Ivanov, 2020) and creates expectations and fear among employees that they may lose their jobs and be replaced (Fiaidhi, Mohammed, \& Mohammed, 2018; McClure, 2018; Nam, 2019; Spencer, 2018; Stubbs, 2017). Claims in recent studies that $47 \%$ of jobs in the US (Frey \& Osborne, 2017) and in other countries (Dengler \& Matthes, 2018) are susceptible to computerisation put more fuel into the fear engine that employees will become obsolete in a robonomic society (Ivanov, 2017) and bring back memories from the $19^{\text {th }}$ century Luddite movement (Jones, 2006). Furthermore, the use of ATs raises concerns regarding what individuals, companies, and social institutions should do if the automation fears are materialised into severe technological unemployment (Feldmann, 2013; Postel-Vinay, 2002; Walsh, 2018).

The traditional resistance to new technologies, as per the Luddites, also brings up a deeper philosophical and practical implications in terms of the current technological revolution, as highlighted in discussions of the "ironies of automation." The "irony" is a discussion regarding how the current wave of automation differs from "classical automation" (Bainbridge, 1983: 778), since it puts human operators in a very different position from the earlier wave of automation. While fears of automation in earlier waves of automation were largely based upon the replacement of human labour for repetitive tasks, the tasks automated under the current wave of automation places greater responsibility upon human operators and leaves the human with little support to deal with the remaining tasks relegated to humans (Baxter et al. 2012; Strauch, 2017). So while early Luddite opposition to AT was largely out of fear of losing jobs, the current resistance to AT may also be influenced by concerns regarding creating difficult and sophisticated situations for humans. Worker resistance to automation may actually be partly based upon resistance to an increasingly complex workplace, since many workplace processes that are not easily automated will be left in the hands of the human operator who is often not given adequate support to handle such tasks [some excellent examples of this are outlined by Baxter et al. (2012)].

This paper addresses the automation fears of employees and the solutions to mitigate them by focusing on a transition economy - Bulgaria, unlike previous studies that are concentrated on major world economies such as USA (McClure, 2018; Nam, 2019), Japan (Morikawa, 2017), or Western Europe (Schlögl et al., 2019). A former Soviet bloc country, Bulgaria, is a member of the European Union since $1^{\text {st }}$ January 2007. With a GDP of approximately 55 billion euros (NSI, 2019a), a population of 7 million (NSI, 2019b), and a GDP per capita of around 8000 
euros, Bulgaria is the poorest EU member. At the same time, the severe demographic crisis (low birth rates and emigration) pushes down the unemployment rate to historically low values (3.7\% for July-September 2019, NSI, 2019c) and creates a huge deficit of skilled employees (Dimitrova, 2019). Faced with the lack of workers, companies in the country are already forced to use automation technologies in order to decrease the pressure of the current labour market shortages on their operations, hence sowing the seeds of future replacement effect and fear of automation.

\subsection{Aims and objectives}

In the line of the above discussion, the aims of this paper are: a) to assess the level of fear Bulgarians have of losing their jobs due to the introduction of automation technologies; $b$ ) to identify the factors that have an impact on the fear of automation; $c$ ) to evaluate the support of Bulgarians to various solutions to mitigate automation fears; and $d$ ) to identify the factors that have an impact on the solutions to be used to mitigate the fear of automation. The technological, operational and economic aspects of automation, the automatability of specific jobs/tasks, and the political economy of automation go beyond the scope of this paper.

In this paper, we adopt a non-normative approach that looks into how a population views automation and its fears of it, and analyses the data to uncover some of the drivers of automation fears. The rest of the paper is organised as follows. Section 2 provides a focused review of the previous literature on automation fears and develops the research hypotheses. Section 3 elaborates on the methodology. Sections 4 and 5 present and discuss the results, while Section 6 summaries the theoretical contribution, managerial and policy implications of the paper, and concludes the paper.

\section{Literature review and hypotheses development}

\subsection{Fear of automation}

The impacts of automation technologies, their social implications, and employees' fear of losing their jobs to ATs are not a new research topic. Back in 1930, Keynes warned about the potential technological unemployment but considered it as a temporary phase of economy maladjustment (Keynes, 1930/1965). In 1958, Cuthbert Hurd elaborated on the new professions and job enhancement (or 'position enlargement' in his terminology) that automation would bring, although there were only a few thousand computers in the USA at that time (Hurd, 1958). Later on in 1965, Louis Rago acknowledged the displacement/substitution effect of automation 
technologies but considered that the fears of automation were not justified, because automation created more jobs through lower product prices and the creation of new jobs in areas "where the "added" purchasing power generates "new" demand" (Rago, 1965: 35). Within the next five decades, the growing adoption of automation technologies stimulated automation fears not only among manufacturing workers, but among service employees and farmers as well; giving ground to Stimmer (1984) to ask whether technology is 'a curse or blessing,' while Brynjolffson and McAfee (2015) queried whether humans will 'go the way of horses.'

The fear of automation is stemming from people's perceptions of losing their jobs to automation and, if they do, how easily they would be able to find a new job in the same or another industry so that they do not find themselves in a financially stressful situation. If automation is not substituting human employees, but in contrast, enhancing them, they would not fear automation and may find it as a tool to achieve higher productivity and greater personal economic wellbeing, unless employees enjoy the specific tasks being replaced. However, the substitution effect of ATs makes human employees uncertain about their future, thus causing fear of losing their jobs. Looking at the broader social effects of automation technologies, Leonhard (2016), Crews (2016), and Barrat, (2013) paint a very grim picture on the impact of robotics and artificial intelligence on employment. From a supply-side perspective, Frey and Osborne (2017), Berg, Buffie, and Zanna (2018), and Autor and Salomons (2018), among others, find that the balance between the enhancement and substitution effects of ATs is definitely on the side of substitution. In a similar vein, DeCanio (2016) shows that the introduction of AI would depress wages of human employees due to the substitution effect. Hence, humans have every reason to fear that they would not only be replaced by technology, but they may face difficulties in finding new jobs in the same or other industries due to widespread automation or lack of skills to work on the newly created jobs.

However, Arntz, Gregory, and Zierahn (2017) consider that the claims about the loss of jobs due to automation are largely exaggerated because of their disregard for the different skills that constitute the jobs. Additionally, Frank et al. (2019) warn that it is very difficult to actually measure the impact of automation on jobs due to lack of high-quality data about the nature of work, lack of empirically informed models of key microlevel processes, and insufficient understanding of how cognitive technologies interact with broader economic dynamics and institutional mechanisms. Therefore, the empirical support for the fears of automation may be shaky. Moreover, Walsh (2018) finds that non-experts are more pessimistic than experts in 
robotics and artificial intelligence and systematically overstate the risk of automation of jobs. Danaher (2019) goes even further and claims that although automation will substitute human employees in the long-term, people should embrace automation and the elimination of work because work is inherently detrimental and impedes human flourishing and meaningful life. In the same line of thought, Brynjolfsson and McAfee (2014), Drexler (2013), Frank, Roehring, and Pring (2017), LaGrandeur and Hughes (2017), Talwar et al. (2017) and others consider that humans should not fear automation technologies because they would have a positive impact on society not only by liberating humans from repetitive, tedious, dangerous, and dirty jobs; but by providing new opportunities for creating value for humans, improving life, and improving the wellbeing of humans in economic, health, and social terms as well. Therefore, although the substitution effect of ATs would be significant in the long-term, it should not be a reasonable basis for automation fears.

From an employee perspective, McClure (2018) found that technophobes in the US who fear automation are fewer in number than non-technophobes. On average, they tend to be older, female, and have lower education. Based on a sample of 10,000 Japanese respondents, Morikawa (2017) concludes that about $30 \%$ of respondents are afraid of losing their job to robotics and AI, while gender, age, education, and type of labour contract are influencing the perceived risk of losing their job. Schlögl et al. (2019) report that employees fear that they would lose their jobs when mundane repetitive tasks are increasingly replaced by AI tools and technologies. The fear is increased due to the lack of information and knowledge about AI. This is supported by Nam (2019) who reports that people aware of the impacts of automations on the labour market tend to be more optimistic and less sceptic. Milosavljević and Vobič (2019) investigate the fear of ATs of journalists in the United Kingdom, Germany, and the United States. The authors find that the journalists consider the new technologies as liberating rather than subordinating them.

\subsection{Potential factors influencing the fear of automation}

\subsubsection{General perceptions of automation technologies:}

People can have both positive and negative perceptions about the role of automation technologies in society. The perceived social benefits of automation technologies usually include benefits such as making the lives of people easier and more convenient, eliminating tedious work for human employees, and improving the standard of living by decreasing the prices of goods and services (Brynjolfsson \& McAfee, 2014; Drexler, 2013; Talwar et al., 
2017). When automation technologies have high perceived benefits for societies as a whole, companies and public institutions would be inclined to implement them. Although some employees would be displaced, the higher perceived social benefits of automation may (partially) off-set the fear of employees for their jobs due to the positive effect of ATs on society. At the same time, people may fear automation technologies because of the negative dehumanisation effects they may have on society such as damaging human relationships, dehumanisation of the workplace, and deskilling of jobs (Bhattacharyya, \& Nair, 2019; Danaher, 2019; Leonhard, 2016). This means that automation technologies would make human employees replaceable and society would need to adjust to automation technologies, not the other way around. Hence, the following two hypotheses are formulated:

H1.1. Perceived social benefits of automation technologies are negatively related to the fear of automation

H1.2. Perceived dehumanisation effect of automation technologies is positively related to the fear of automation

\subsubsection{Characteristics of automation technologies as production factors compared to human} employees

From an economic point of view, automation technologies are production factors. As such they have both advantages and disadvantages compared to human employees. For example, ATs process information much faster than humans and can provide more accurate information with fewer mistakes, they are more reliable than humans, have higher productivity and greater cost efficiency than human employees. Some of the perceived disadvantages of automation technologies include the lack of creativity, less interactive than humans, and operating mostly in highly structured/standard situations (Ivanov, 2019), among others. When automation technologies have more advantages compared to human employees, companies would prefer to use them instead of human employees, thus nurturing automation fears among their employees. On the opposite, when people perceive that they are more competitive than automation technologies they would feel more secure about their jobs. Hence the following two hypotheses are formulated:

H2.1. Perceived advantages of automation technologies compared to human employees are positively related to the fear of automation technologies 
H2.2. Perceived disadvantages of automation technologies compared to human employees are negatively related to the fear of automation technologies

\subsubsection{Self-image of human employees}

Prior studies have indicated that the image people have about themselves is influencing the way the behave (Schiffman et al., 2014), the products they buy (Johe \& Bhullar, 2016), and their attitudes towards and acceptance of new technologies (Nikou \& Economides, 2017). Within this research we consider three characteristics of human employees - innovativeness, professionalism and technological skills. Innovative people try to find new solutions to existing problems and have creative and original thinking (Wiedmann et al., 2010). Creativity is their competitive advantage over automation technologies. This means that they cannot be easily replaced by technology, but even when faced with a potential threat of substitution they may not be frustrated but will look for new ways to develop and remain competitive. Hence:

H3.1. People who consider themselves as innovative are less afraid of losing their jobs to automation technologies

Professionalism refers to how well a person is prepared for and performs the tasks within his/her job, although there is some literature that struggles to define and conceptualise the term with more precision (see, for example, Bossers et al., 1999). Companies try to attract and keep employees that deliver high quality, effective and efficient work. There is some indication that robots may threaten certain management positions more than others, typically less-skilled managers (Dahlin, 2019). Therefore, people with high self-perception of professionalism may be more confident that they will keep their jobs, will not be replaced or, in case they are replaced, they can find new job relatively easily. Hence:

H3.2. People who consider themselves as professionals are less afraid of losing their jobs to automation technologies

Finally, technological skills refer to how confident human employees are in using various technologies. The likely impact of technological skills on fear of automation is not very straightforward. On the one hand, people who feel comfortable with technology, and are confident that they have the knowledge and skills to use automation technologies, will also be able to use these technologies in their favour - e.g. for being more productive on their job (this 
is the enhancement effect of automation). On the other hand, the high level of technological skills means that these people will also have greater knowledge about the capabilities of new technologies and their potential for replacing human employees. Moreover, higher technological skills are associated to low supply of human employees with such skills and higher labour costs for them, thus greater economic pressure for companies to decrease their dependency on such skills. A recent study confirms that due to automation and artificial intelligence, technological skills will be in high demand in the future (Bughin et al., 2018). Balancing on this discussion the following hypothesis is formulated:

H3.3. People with higher technological skills are afraid of losing their jobs to automation technologies

\subsubsection{Demographic characteristics of human employees}

Demographic characteristics have been found to influence perceptions towards automation technologies such as robots (Ivanov, Webster, \& Garenko, 2018; Ivanov, Webster, \& Seyyedi, 2018). In regard to fear of automation demographic characteristics of human employees may play a role too. Blue collar jobs, that have historically been ousted by industrial robots, are usually occupied by men. Statistical data by International Labour Organization (ILO, 2019a) show that globally men dominate in manufacturing, construction, and transport and storage, where industrial and warehouse robots and autonomous vehicles would be introduced in the future. Data by Bulgarian National Statistics Institute (NSI, 2019d) reveal the same picture on country level. On the other hand, men also hold more managerial positions than women (ILO, 2019b) which are less automatable than operational level jobs (see section 2.2.5 further in the text). Women dominate in professions where emotional intelligence and social skills are key requirements (e.g. services) which are more difficult to automate than manufacturing jobs (ILO, 2019a). At the same time, despite the antidiscrimination laws, women are often in a disadvantaged position when looking for high-paid managerial jobs (Dencker, 2008; Hultin \& Szulkin, 1999). Furthermore, as prior Kral et al. (2019) have indicated, automation will have different impact on men and women due to the different levels of automatability of the jobs they usually occupy (see section 2.2.5 as well). Specifically, the authors point out that the job positions occupied by men have greater risk of automation compared to those of women. Therefore, although both genders have their reasons to be afraid of the impacts of automation on their jobs and how easily they can find a new job, the following hypothesis is formulated: 
H4.1. Men have higher fear of automation

Younger people are more tech savvy, they are more mobile and more adaptable to changing situations compared to older generations (Kolnhofer-Derecskei, Reicher \& Szeghegyi, 2017). When they lose their job younger people may find a new job more easily than older employees due to the skills, adaptability, stress endurance, learning capabilities, and readiness to work for longer hours at lower salaries. At the same time, older people may be more afraid of losing their jobs to automation because they are already looking for their retirement and do not want to change their job or spend a lot of time and/or money to requalify for another unautomated job position. Hence, the hypothesis:

H4.2. Younger people are less afraid of losing their jobs to automation technologies

One of the goals of education is to equip students with skills and make them employable. More educated people are supposed to have more knowledge and skills to perform well on their job and will be more competitive on the labour market. This leads to the hypothesis:

H4.3. More educated people are less afraid of losing their jobs to automation technologies

Higher perceived economic wellbeing means that the if a person loses his/her job due to automation, he/she will have sufficient financial resources and may afford a longer search period for a new job. Furthermore, the higher economic wellbeing may be a result of holding job positions at managerial and executive levels that are less likely to be automated. Therefore, the formulated hypothesis is:

H4.4. Perceived economic wellbeing is negatively associated to the fear of automation

People living in metropolitan areas are exposed to more technological innovations because larger cities provide greater economies of scale for the introduction of new technologies. Prior studies have shown that the place of living (city size) was shaping people's attitudes towards technology in a way that people in metropolitan areas have more positive attitudes towards automation technologies (Ivanov, Webster \& Garenko, 2018). Furthermore, larger metropolitan areas provide greater job opportunities compared to smaller areas. The limited job opportunities outside metropolitan areas increase the time and efforts that displaced workers would need to 
spend to find new jobs. Hence, they may be more afraid of losing their jobs to automation technologies compared to people in metropolitan areas. The formulated hypothesis is:

H4.5. People living outside the metropolitan areas are more afraid of losing their jobs to automation technologies

\subsubsection{Job characteristics}

The automatability of a job position and its level within the organisational structure of the company determine the probability of a job being automated. Each job consists of a series of tasks. At the current state of technological development some tasks (e.g. routine / repetitive tasks, calculations, information processing, moving objects) are easier to automate than others (e.g. non-routine tasks, or tasks that require emotional intelligence and social skills) through physical or cognitive automation (Ivanov, 2020). When most of the tasks that consist a job position are automatable, then the whole jobs position becomes automatable. This means that if various technologies are introduced to perform the automatable tasks of that job position, the remaining tasks will be too few to justify the existence of the whole job position - it will be eliminated and the remaining unautomated tasks would be transferred to other job positions. Therefore, people whose jobs comprise of predominantly automatable tasks have all the reasons to fear that they would be substituted by automation technologies. Coupe (2019), for example, finds that people whose jobs involve a lot of personal interaction are less afraid of losing their jobs to ATs. Therefore, the following hypothesis is formulated:

H5.1. Job automatability is positively related to automation fear

Each job position has its place in the organisational hierarchy. The job level (operational, supervisory, managerial or executive) determines not only the types of tasks that are included in the job position, but also the involvement of the employee in the decision making process, especially for the introduction of ATs. Higher level job positions (managerial and executive) take the practical decisions to introduce automation technologies in company's operations. People on these levels are also fewer compared to employees on operational and supervisory level, and their job positions include tasks that are not always easy or desirable to automate (e.g. strategic decision making). Therefore, larger impact of automation (in terms of number of eliminated job positions) may be achieved by automating jobs on operational and supervisory 
levels whose job positions include tasks that are often standardised and automatable. That is why, the formulated hypothesis is:

H5.2. Lower job positions are associated to higher fear of automation

\subsubsection{Work experience}

In this paper the work experience is measured in two ways: by the total number of years a person worked, and the number of years a person worked on a particular job position. A person with greater work experience would be more confident that he/she performs well (effectively and efficiently) on the job because of the direct work experience he/she has on that same job or the overall accumulated work experience. Hence he/she may not fear so much of losing his/her job to automation or may use this experience as a competitive advantage to find a new job elsewhere if replaced by technology. Therefore, we hypothesise that a negative relationship would exist between the automation fear and the work experience:

H6.1. Longer work experience is negatively associated to automation fear

H6.2. Number of years on a particular job position is negatively associated to automation fear

\subsubsection{Social influence}

Social influence (TV news and shows, online media, posts in social media and blogs, conversations with colleagues, friends and relatives, etc.) has been found to have an impact on people's behaviour and opinions about vast range of topics, including automation technology (Madigan et al., 2017). The information people are exposed to at work, at home, with friends, or online, contributes to the formation of specific attitudes towards technologies (positive or negative). The social influence may both increase or decrease the fear of automation. For example, if a person is exposed mostly to information showing that ATs are replacing human employees (e.g. in social media feeds, or a relative lost a job for that reason), he/she might be afraid for his/her job. The opposite is also valid. That is why we cannot hypothesise the exact direction of the impact of social influence but only that such an impact would exist:

H7. Automation fears are shaped by peer pressure

\subsection{Solutions to automation fears}


The solutions to automation fears are in fact solutions to the threat of and consequences of technological unemployment. They can be divided into three groups, depending on who has the responsibility to implement them, namely: individual, corporate and social solutions.

Individual solutions include all those actions that human employees can undertake in order to mitigate the negative consequences of automation on their employability. These actions can be divided into 3 possible strategies - "fight", "flight" or "passive". The "fight" strategy encompasses the action that aim human employees to remain competitive on the labour market by improving their qualification in order to perform on their current jobs better than the automation technologies (i.e. fighting the substitution effect of technology), or by learning how to use automation technology to be more productive on their current jobs (i.e. utilising the enhancement effect of technology). The human employees who have a "flight" strategy look for new jobs that are not going to be automated soon in the same or another industry. Employees with a "passive" strategy avoid proactive behaviour, do nothing, and wait for the automation impacts to unfold.

Corporate solutions include the actions that companies can undertake in order to decrease the fear of and the negative impacts of automation on employment. For example, producers of ATs can evaluate and publicly announce the impact of automation technologies on jobs (Stevens \& Marchant, 2017). In that way, people and governments would be familiar in advance with the likely effect of these technologies in various industries. Additionally, companies that use ATs can evaluate and publicly announce their impact on jobs before these technologies are being adopted. While the evaluations of the producers of automation technologies would refer to industries as a whole, the evaluations of the corporate users of these technologies would provide more specific light on the exact impacts on particular companies. These two measures do not necessarily mean that the fear of automation would be mitigated (the effect can be even opposite - i.e. increased fear) but at least they can provide an indication about the impact of automation technologies on jobs. Furthermore, when companies have already opted for the introduction of ATs, they could mitigate the fears of their employees by introducing work sharing and reduced working hours (i.e. decreasing slightly the fear of losing a job) (Stevens \& Marchant, 2017) and by providing free requalification for displaced employees (i.e. improving the chances of finding a new job). Ultimately, consumers can contribute to the decrease of automation fears by boycotting companies that substitute their employees with ATs. Although not a pure corporate solution, it may have an impact on the decisions of companies about automation. 
Social solutions include a set of economic and administrative actions of governments and public institution directed not towards the automation fears of specific persons but to the society as a whole (Ivanov, 2017; Nam, 2019; Stevens \& Marchant, 2017). For instance, the government may provide free education to everyone to improve their qualification in order to be more productive and be able to use effectively and efficiently automation technologies (enhancement effect), or it can provide free education only to those who have lost their jobs due to automation (mitigating the negative impacts of displacement). The government may create financial incentives to companies to use human employees rather than ATs (e.g. tax vacations, covering the costs for social security and medical insurance payments) but such measures may turn out to be too costly for governments' budgets. Companies may also have opportunistic behaviour and threaten to automate processes if the government does not provide them with subsidies to keep the human employees. Hence, in the long-term this solution does not seem viable. Government could hire everyone who has lost his/her job due to automation technologies. In that way they would directly decrease or even eliminate the fear of automation, because human employees would know that they have the safety net of government-created employment. If the substitution effect of ATs is massive, the government would not cope with the influx of displaced workers. It will fail not only in creating jobs, but also in financing these jobs, because its budget revenues would suffer due to unemployment-induced drop in income taxes. Thus, although socially pleasing, this option may not be financially feasible. Governments could try to tax automation technologies (Ionescu, 2019). However, this would require very precise legal definition of automation technologies. Once a legal definition is introduced, automation technologies' manufacturers would try to change their products in ways that go beyond the scope of their legal definition, thus making it practically challenging to collect the taxes. Another solution may be the provision of basic income (McDonough \& Bustillos Morales, 2020; Sheahen, 2012). It would guarantee that even when left without work-related income, employees would continue to receive some unconditional income from the government (unlike social payments that are usually tight to specific conditions such as disability or have limited duration). Basic income would decrease the fear of employees of being left without financial resources as a result of automation. Strict birth control on populations as a radical measure on fighting technological unemployment has been proposed in the literature too (Ivanov, 2017).

Clearly the different solutions, sketched briefly above, are strongly politically charged. Conservatives and liberals would probably give preference to individual solutions, socialists - 
to governmental solutions, while social democrats may reply on all of them with an emphasis on corporate and social. However, it goes beyond the scope of this paper to discuss the role of political ideologies in mitigating the negative impacts of automation on employment, which could be subject of future research.

\subsection{Potential factors influencing the support to the solution to automation fears}

\subsubsection{Demographic characteristics of human employees}

If demographic characteristics (age, gender, education, perceived economic wellbeing, and place of living) shape the automation fears (see Section 2.2.4.), it is likely that they also do this regarding the acceptance of the various solutions to automation fears (see also Nam, 2019). Older employees may prefer corporate and social solutions over individual ones because they find it challenging to be proactive and learn new skills to use automation technologies on their workplace. More educated employees may be more confident in their knowledge, skills, and competitiveness on the labour market and may prefer individual solutions. Less affluent employees might focus on corporate and social solutions as a more financially reasonable solution for them personally. While people in metropolitan areas could rely more on their own efforts due to the greater job opportunities compared to non-metropolitan areas. Hence, the following hypotheses are developed.

H8.1. Gender influences the support for the solutions to automation fears

H8.2. Age influences the support for the solutions to automation fears

H8.3. Education influences the support for the solutions to automation fears

H8.4. Perceived economic wellbeing influences the support for the solutions to automation fears

H8.5. Place of living influences the support for the solutions to automation fears

\subsubsection{Job level}

Corporate solutions directly hit the finances of companies. Therefore, people on managerial and executive levels may not be supportive to such solutions because their bonuses would suffer and may prefer individual and social solutions. At the same time, some of the corporate solutions (e.g. free requalification of employees) are integral part of corporate social responsibility and are likely to be supported by managers. Employees on an operational and supervisory level would expect companies to take care of them if displaced by automation; that is why they may have greater preference about corporate solutions compared to individual ones. The hypothesis is: 
H9. Job level influences the support for the solutions to automation fears

\subsubsection{Work experience}

The influence of work experience on the support for the solutions is not clear cut. On the one hand, as elaborated in 2.2.6 employees with longer work experience are more confident that they would find a job if replaced by automation; hence they may support the individual solutions to automation fears. On the other hand, longer work experience (e.g. 30 years or more) is connected to older age which may weaken the support for individual solutions in favour of corporate and social. Therefore, the hypothesis is:

H10. Work experience influences the support for the solutions to automation fears

\section{Methodology}

\subsection{Data collection procedures}

Data were collected during May-June 2019. The link to an online questionnaire was distributed through social media. The authors posted it to different social media groups in order to reach respondents with diverse demographic backgrounds. The administrators of one of the most popular Facebook pages in Bulgaria ("Science and critical thinking") shared the link to the survey which helped reach a larger audience. Participation in the research was voluntary and entirely anonymous - no personal identifying information was collected. Respondents selfselected to participate in the research. The questionnaire was originally developed in English language and then translated into Bulgarian by the first and second authors who are native speakers. It took about 15 minutes to complete the questionnaire.

\subsection{Data collection instrument}

The questionnaire consisted of 86 individual questions divided into several blocks. The first block collected demographic data about the respondents. The second block examined the attitudes towards automation technologies (general attitudes, perceived social benefits and negative social impacts of automation technologies, advantages and disadvantages of automation technologies as production factors compared to human employees). The third block included questions related to respondents' self-perception (technological skills, professionalism, and perceived social influence). The questions in the fourth block related to the possibility to automation of the current job of the respondent and his/her fear of automation 
technologies. The final block included various statements related to possible governmental and corporate solutions to automation fears of Bulgarians. The level of agreement to all statements was measured with a 7-point Likert scale (from 1-completely disagree to 7-completely agree). For some statements such as those related to dehumanisation impacts of automation technologies, their disadvantages compared to human employees, the job automatability, and the fear of automation, reverse coding was adopted. The three attitudinal statements were measured on a 7-point scale as well (from 1-extremely negative to 7-extremely positive). Appendix 1 specifies the items in the scales and their sources.

\subsection{Data analysis methods}

Cluster analysis helped identify segments of respondents on the basis of their fear of automation. The number of respondents in the cluster analysis (502) was 83.7 times higher than the number of variables in the segmentation base (6 statements). Therefore, it exceeded the minimum ratio of 70 recommended by Dolnicar et al. (2014). The Kolmogorov-Smirnov and Shapiro-Wilk tests revealed that for most questions the distribution of responses was statistically different from normal. That is why non-parametric tests were adopted for hypothesis testing. In particular, Mann-Whitney U-test was used to identify differences in respondents' answers on the basis of gender and cluster belongingness, while Kruskal-Wallis $\chi 2$-test was adopted for analysing the differences on the basis of the age, education, perceived economic wellbeing, work experience, and job level of respondents. Wilcoxon signed ranks test was applied to identity differences in respondents' answers to some questions. Furthermore, factor analysis and regression analysis were used to identify the impacts of various factors on automation fears of respondents.

\subsection{Sample's characteristics}

The research population included Bulgarian citizens above the age of 18 . The authors deliberately looked for respondents not only from Bulgarians living within the country, but for Bulgarian citizens living abroad as well in order to see whether the different cultural and economic environment Bulgarians living abroad face (e.g. in Western European countries, or in the USA) has an impact on the fears of automations. In total 606 respondents completed the survey, but 104 responses had to be removed due to missing answers to numerous questions. The final dataset included 502 respondents. Table 1 presents the demographic characteristics of the sample. 


\section{INSERT TABLE 1 AROUND HERE}

\section{Results}

\subsection{The general picture}

In general, the attitude of Bulgarians towards automation is extremely positive $(m=6.17)$, with similar positive perceived impacts of automation technologies on society both currently $(m=5.95)$ and in the near future $(m=5.94)$ (see Table 2$)$. This is further evidenced by the fact that respondents consider that the perceived benefits of automation for society $(\mathrm{min} \mathrm{m}=4.39$, $\max \mathrm{m}=6.04)$ outweigh the expected negative dehumanisation impacts of automation technologies ( $\min \mathrm{m}=2.70, \max \mathrm{m}=4.37$, reverse coding). In the same vein, the advantages of ATs compared to human employees $(\min \mathrm{m}=5.30, \max \mathrm{m}=6.19)$ are stronger than their disadvantages $(\min \mathrm{m}=2.58, \max \mathrm{m}=4.77$, reverse coding). Respondents also consider themselves as relatively innovative persons $(\min \mathrm{m}=4.77, \max \mathrm{m}=5.85$ ), with very good technological skills $(\mathrm{min} \mathrm{m}=5.57, \max \mathrm{m}=6.21$ ) and high level of professionalism $(\mathrm{min} \mathrm{m}=5.66$, max $m=6.18$ ). Additionally, they remain generally neutral regarding the automatability of their job positions $(\min \mathrm{m}=3.46, \max \mathrm{m}=4.44$, reverse coding). Hence, the respondents do not show fear of losing their jobs to automation technologies ( $\min \mathrm{m}=5.61, \max \mathrm{m}=6.00$, reverse coding).

\section{INSERT TABLE 2 AROUND HERE}

\subsection{Cluster analysis and hypothesis testing}

A closer look at the data shows that the respondents are not uniform in their answers. The cluster analysis revealed the existence of two large groups of respondents on the basis of their fear of automations (Table 3). The first group ('Confidents') consists of 398 respondents who have a very low level of fear on each of the six statements ( $\min \mathrm{m}=6.03, \max \mathrm{m}=6.37$, reverse coding). The second group ('Neutrals') includes 104 respondents who have generally provided a neutral answer to the statements of fear ( $\min \mathrm{m}=3.77$, $\max \mathrm{m}=4.57$, reverse coding). Table 3 shows that the two clusters are similar in terms of their demographic characteristics (age, gender, education, and place of living), while the 'Neutrals' have a slightly lower perceived economic wellbeing than the 'Confidents' $(\chi 2=15.764, \mathrm{p}<0.05)$. The differences in the responses of the two groups are mostly statistically significant as the 'Confidents' are systematically more optimistic than the 'Neutrals' (see Table 3). It should be noted that very few respondents actually agreed with the fear statements. As a matter of fact, as low as 29 respondents (or 5.8\%) strongly agreed, agreed or somewhat agreed with the statement "I fear I might lose my current 
job due to automation technologies within the next 5 years," while as high as 64 of them $(12.7 \%)$ strongly agreed, agreed or somewhat agreed with the statement "I fear that the use of automation technologies on my current job will require knowledge and skills that I do not have.”

\section{INSERT TABLE 3 AROUND HERE}

The Mann-Whitney U-test and Kruskal-Wallis $\chi 2$-test showed that gender, education, perceived economic wellbeing, and job level have no or marginal effect on fear of automation (Table 2) (Hypotheses H4.1, H4.3, H4.4, H5.2). Age seems to condition the fear of automation as younger respondents (18-30) are less afraid of automation compared to middle aged (41-50 and 51-60) respondents - they are less afraid to lose their jobs within the next five years $(\chi 2=16.675$, $\mathrm{p}<0.01)$, or that they will not be able to find a new job in the same $(\chi 2=13.767, \mathrm{p}<0.01)$ or in another industry $(\chi 2=17.836, \mathrm{p}<0.001)$ (Hypothesis H4.2). This might be a result of the demographic crisis that Bulgaria is currently experiencing which gives more bargaining power to the younger employees who are fewer, but more educated and mobile compared to the previous generations. Additionally, respondents with longer work experience (21-30 years) are more afraid than less experienced ones (0-10 and 11-20 years) that if they lose their job due to automation, they might not be able to find a new job in the same $(\chi 2=14.944, p<0.01)$ or another industry $(\chi 2=16.453, \mathrm{p}<0.001)$ (Hypothesis H6.1). These results; however, might not be related so much to the actual work experience of respondents than to their plans and expectations about the upcoming retirement age. Hence, in their eyes, if they lose their jobs to ATs, they might not be able to requalify to gain new job skills and their age might be a hindrance to being hired by another company in the same or another industry. In any case, the data do not allow us to confirm or refute this conjecture. Unsurprisingly, respondents from Sofia (the capital of Bulgaria, its most developed city, and the only city in the country with over one million inhabitants) have more positive attitude towards automation technologies and consider that they will make life easier $(\chi 2=11.114, p<0.01)$, more convenient $(\chi 2=10.483, p<0.01)$, and will eliminate tedious work $(\chi 2=11.907, \mathrm{p}<0.01)$. They are also less afraid of the deskilling effect of automation technologies on their jobs $(\chi 2=8.248, \mathrm{p}<0.05)$. However, the effect of place of living on automation fears remains marginal (Hypothesis H4.5).

Looking at the other statements on Table 2 some additional conclusions can be made. In terms of gender, men evaluate the benefits of automation technologies for society and their advantages compared to human employees much higher than women do (most $\mathrm{p}<0.001$ ). Part of the 
explanation for this result might be the greater confidence male respondents reported to have compared to females in regard to the use of computers $(U=23161.5, p<0.001)$ and electronic devices $(\mathrm{U}=24436.5, \mathrm{p}<0.001)$, and in their knowledge and skills to use automation technologies $(\mathrm{U}=22267, \mathrm{p}<0.001)$. Respondents with higher perceived economic wellbeing agree more with the statements that ATs improve the standard of living $(\chi 2=15.015, p<0.001)$ and make our life more convenient $(\chi 2=13.187, \mathrm{p}<0.001)$ compared to respondents with average and lower perceived economic wellbeing. Moreover, they have more positive perceptions about the current $(\chi 2=20.840, p<0.001)$ and future $(\chi 2=15.223, p<0.001)$ impacts of automation technologies on their lives. It seems that a person's economic comfort gives the individual the sense of security that undermines the fears of automation. Thus, economic vulnerability may actually be the construct that makes respondents wary of technological threats to whatever wealth that they have in life.

\subsection{Factor analysis}

Table 4 presents the results of the factor analysis. As evident from the values of Cronbach alpha (above 0.7) and composite reliability (above 0.8), all constructs have high convergent reliability. For one of the factors ('Disadvantages' of automation technologies compared to human employees) the Cronbach alpha is just below the acceptable value $(\alpha=0.691)$ but the respective composite reliability value $(\mathrm{CR}=0.801)$ is sufficiently high. Two of the items in the 'Dehumanisation' factor, and one in 'Technological skills' were deleted due to low factor loadings. The average extracted variance (AVE) ranges from $39.412 \%$ ('Disadvantages') to $66.577 \%$ ('Professionalism'). Table 5 compares the square root of AVE of the constructs (on the diagonal) with the inter-construct bivariate Pearson correlations (below the diagonal). The results confirm the discriminant validity of the factors because the square root of AVE of each construct is higher than the bivariate Pearson correlations with the other constructs, hence the factors are sufficiently distinct from each other and can be used in regression analysis as independent variables.

\section{INSERT TABLE 4 AROUND HERE \\ INSERT TABLE 5 AROUND HERE}

\subsection{Regression analysis}

Table 6 presents the regression analysis results. Two models were developed. Model 1 considers only the constructs, while Model 2 includes other control variables as well. The values 
of the VIF and tolerance statistics indicate that there is no multicollinearity. The models have good predictive power, explaining 28.8\% (Model 1) and 29.7\% (Model 2) of the variation of the dependent variable. The findings reveal that the fear of automation is stimulated by the perceptions of dehumanisation impacts of automation technologies on society as whole (Model 1: $\mathrm{t}=4.196, \mathrm{p}<0.001$; Model 2: $\mathrm{t}=4.023, \mathrm{p}<0.001$ ) (Hypothesis H1.2), the automatability of a person's job (Model 1: $\mathrm{t}=7.083$, $\mathrm{p}<0.001$; Model 2: $\mathrm{t}=7.203$, $\mathrm{p}<0.001$ ) (Hypothesis H5.1), and social influence (Model 1: $\mathrm{t}=-3.380, \mathrm{p}<0.001$; Model 2: $\mathrm{t}=-3.130, \mathrm{p}<0.001$ - note that fear, unlike social influence, is a reverse coded variable, thus a minus sign indicates a positive relationship) (Hypothesis H7). At the same time, higher self-image of professionalism decreases the fear of automation (Model 1: $\mathrm{t}=3.591, \mathrm{p}<0.001$; Model 2: $\mathrm{t}=3.884, \mathrm{p}<0.001-$ due to the coding of fear statements, the positive sign here indicates a negative relationship) (Hypothesis H3.2). Put in other words, the fear of automation is nurtured by a respondent's generally negative opinion about the impacts of automation technology on society, the characteristics of his/her job and how easily it can be automated, and the peer pressure. On the other hand, confidence in the preparedness to work at the current (most recent) job, good work performance, and staying up to date with the latest developments in the field, decrease the fear of respondents of losing their jobs due to automation. All other variables ('Perceived benefits' /H1.1/, 'Advantages' of automation technologies compared to human employees $/ \mathrm{H} 2.1 /$, 'Innovative personality'/H3.1/, 'Technological skills'/H3.3/, work experience/H6.1/, years on the job /H6.2/, job level /H5.2/, education /H4.3/, age /H4.2/, and gender /H4.1/) do not seem to be related to the fear of automation.

\section{INSERT TABLE 6 AROUND HERE}

Figure 1 summarises the factors that influence the fear of automation.

\section{INSERT FIGURE 1 AROUND HERE}

\subsection{Solutions to automation fears}

Table 7 presents the findings about individual and social solutions that can be implemented by the respondents themselves, by the governments or corporations in order to decrease the fear of automation. Results clearly indicate that respondents prefer individual solutions such as to learn how to utilise automation technologies and be more productive on their current jobs $(\mathrm{m}=6.01)$ and improve their qualifications $(\mathrm{m}=5.43)$, and the differences with the average responses to 
the statements for the other solutions are statistically significant (all Wilcoxon signed ranks test values significant at $\mathrm{p}<0.001)$. Furthermore, corporate solutions such as free qualification for displaced employees $(m=4.99)$, work sharing and reduced working hours $(m=4.69)$, evaluation of the impacts of ATs on jobs by manufacturers $(\mathrm{m}=4.49)$, and users of technologies $(\mathrm{m}=4.48)$ find some support among Bulgarians. However, social solutions that require the involvements of the government such as taxing automation technologies $(\mathrm{m}=3.14)$, provision of basic income guarantee $(\mathrm{m}=3.07)$ or hiring people displaced by automation $(\mathrm{m}=2.53)$ are generally rejected, with the exception of the provision of free education $(\mathrm{m}=4.71)$. Therefore, we may conclude that respondents consider that solutions to automation fears lie first in the hands of the employees, then the corporations, and, finally - the government; i.e., those most affected by automation have the responsibility to cope with its consequences.

\section{INSERT TABLE 7 AROUND HERE}

The Mann-Whitney U-test and Kruskal-Wallis $\chi 2$-test showed that age (Hypothesis H8.2), education (H8.3), work experience (H10), and job level (H9) have no or negligible effect on respondents' support for the solutions to automation fears (Table 7). Female respondents seem more socially engaged than males and provide more support to social solutions such as basic income for displaced workers $(\mathrm{U}=22231.5, \mathrm{p}<0.001)$, taxing automation technologies $(\mathrm{U}=25301.5, \mathrm{p}<0.001)$, government obligation to hire all displaced workers $(\mathrm{U}=23604.5$, $\mathrm{p}<0.001$ ), and financial incentives to companies to use human employees instead of ATs $(\mathrm{U}=23604.5, \mathrm{p}<0.001)$ (Hypothesis H8.1). However, both females and males have generally very low support to government-regulated social solutions. The 'Confidents' are more eager to learn how to use automation technologies $(U=15781, p<0.001)$ and improve their qualification $(\mathrm{U}=17695, \mathrm{p}<0.05)$, while the 'Neutrals' prefer to search for a new job in the same $(U=16134$, $\mathrm{p}<0.001)$ or another industry $(\mathrm{U}=14329, \mathrm{p}<0.001)$. Metaphorically, we can say that the 'Confidents' prefer to fight, with the 'Neutrals' - to flight. Furthermore, the 'Neutral' provide much greater support to the social and corporate solutions than the 'Confidents', hence transferring the responsibility of finding a solution from themselves to the companies and, especially, the government. Additionally, respondents with a perceived economic wellbeing lower than the average for the country are more supportive of free education $(\chi 2=10.217$, $\mathrm{p}<0.01)$, taxing automation technologies $(\chi 2=11.134, \mathrm{p}<0.01)$, and evaluation of the impact of automation technologies by their producers $(\chi 2=12.794, p<0.01)$ and users $(\chi 2=14.786$, $\mathrm{p}<0.001$ ) (Hypothesis H8.4). Finally, respondents living in the capital city are much less 
inclined to accept government-created jobs $(\chi 2=11.257, \mathrm{p}<0.01)$ or financial support to companies for job creation $(\chi 2=10.004, \mathrm{p}<0.01)$ (Hypothesis H8.5).

\section{INSERT TABLE 8 AROUND HERE}

The exploratory factor analysis of the solutions statements (see Table 8) extracted five factors which we named 'Economic solutions,' 'Targeted solutions,' 'Socialist solutions,' 'Escapism,' and 'Self-improvement' with relatively high composite reliability values (excluding for 'Targeted solutions') that explain $60.695 \%$ of the variance in respondents' answers. The first group, 'Economic solutions' ( $\mathrm{CR}=0.867, \mathrm{VE}=27.671 \%$ ), includes solutions to automation fears that require AT manufacturers and users to evaluation the impact of these technologies on jobs, involve the government through taxes on automation technologies and financial incentives for companies to use human employees, and customers' boycott of companies that substitute employees with automation technologies. All these solutions are strong economic mechanisms of managing the impacts of ATs on jobs, hence the name of the group. The second group, 'Targeted solutions' ( $\mathrm{CR}=0.641, \mathrm{VE}=10.224 \%)$, includes mostly actions targeted to those human workers who have lost their jobs due to automation, namely free education, government employment, and basic income. The third group, 'Socialist solutions' ( $\mathrm{CR}=0.726$, $\mathrm{VE}=8.682 \%$ ), includes mostly actions that are mostly directed to all employees such as work sharing and reduced working hours, free education, and basic income for all citizens. The fourth group, 'Escapism' (CR=0.922, VE=7.394\%), includes individual actions related to looking for a new unautomatable job in the same or another industry, while the last fifth group, 'Selfimprovement' $(\mathrm{CR}=0.878, \mathrm{VE}=6.724 \%)$ includes two individual proactive solutions related to increasing the qualification and learning to use automation technologies in order to be more productive.

Table 9 provides the summary results for the hypotheses.

\section{INSERT TABLE 9 AROUND HERE}

\section{Discussion}

The findings illustrate a great deal about how people approach the challenges of automation in the workplace and their preferred solutions to problems introduced by automation. The data show that there are demographic and attitudinal segmentations of the population that give 
analytical insight into understanding how people approach automation and the policy solutions they prefer with regards to the challenges of the automation of the workplace. From the most descriptive of statistics from the data, we see that the Bulgarian sample is consistent with McClure's (2018) findings of a US sample - technophobes are a minority. We see that respondents have few fears of being replaced by automation in the workplace (as Table 2 shows), illustrating that the respondents are not particularly concerned about automation technologies in the workplace. These data also show that respondents generally are of the mindset that technologies are not likely to be substitutes for human labour. So it seems that from a broad perspective, the respondents do not fear going "the way of the horse," something speculated that would happen to humans in an economy with substantial automation (Brynjolffson \& McAfee; 2015). Thus, the general sentiments of these Bulgarian respondents on ATs runs counter to what others (Autor \& Salomons 2018; Frey \& Osborn, 2017; Berg, Buffie \& Zanna, 2018) in academic literature have speculated. While those academics argue technologies are more likely to replace human labour than enhance it, the respondents in this sample understand the automation in a different way, either not fearing it will replace them or considering it as something enhancing them in the workplace. This finding from the Bulgarian sample runs counter to Walsh's (2018) expectation that people would overestimate the substitutability of automation for human labour.

There are clear segments of the Bulgarian sample who are more concerned about their job security and how new technologies threaten their sense of job security but the segments are not demographically defined. The analysis generally shows that simple demographic variables have little value in terms of explaining variations in fears of automation. This is very true of the "usual suspect" in social science analysis, gender. There is no substantial evidence to suggest that gender influences automation fears among those in the sample, despite the very different jobs that males and females do in the economy. So, while there may be an objective difference in how automation will impact men and women in the workplace (Kral et al., 2019), the findings do not show that gender has an impact upon automation fears. While a great deal of research with regards to automation and perceptions of robots highlights that females and males perceive robots and other technologies differently (see, for example, Hudson et al., 2017; Reick-Stieber \& Eyssel, 2015; Pochwatko et al., 2015; Katz \& Halpern, 2014), there is little or no evidence that females and males experience automation fears differently. However, gender seems to influence so much of the responses in the data analysed apart from automation fears, which 
makes the findings consistent with other research on attitudes towards automation and gender influences (Ivanov, Webster, \& Garenko, 2018; Ivanov, Webster, \& Seyyedi, 2018).

However, there is evidence that the age of respondents impacts upon perceptions towards technology, as speculated by Kolnhofer-Derecskei, Reicher \& Szeghegyi (2017). Indeed, of all the demographic variables investigated to look into what impacts upon the automation fears of this sample, only the age of the respondents seems to influence how respondents perceive issues linked with their job security and career trajectory in a consistent manner. The data show that younger people are more hopeful and flexible, while older people are less flexible and less willing to invest time in retooling themselves for the workplace. So there seems to be evidence that the human life cycle influences how a human looks upon the threat of automation in the workplace.

The other demographic variables are failures in terms of their conditioning of the automation fears of the respondents. For respondents, it seems that their wealth, education, or whether they are urban or rural plays little or no role in influencing how they perceive the threats to their jobs because of automation. While there is evidence that people in urban centres have a different approach to some questions asked of the sample, there is little evidence that whether a person lives in a rural setting or big city that this will influence automation fears. So while the findings of some of the views on automation seem to be occasionally influenced by whether a person lives in an urban or rural environment, something consistent with the findings of other (Ivanov, Webster, and Garenko, 2018; Hudson et al., 2017), it seems that this plays little or no role in how a person fears that automation may threaten jobs/careers. And this is even more true for education levels, as it seems that there is no evidence that the education level of a respondent would influence her/his fears with regards to automation of the workplace. The lack of a relationship of attitudes with the education level of respondents echoes the findings of Ivanov, Webster, and Garenko (2018), showing that education, even if used as lone indicator, shows no important relationship with attitudes towards automation in workplaces.

While demographics, apart from the age of a respondent, fail to explain automation fears, there are some attitudes and characteristics that have some predictive ability to explain automation fears. In terms of attitudes, the findings show that respondents who perceive that automation dehumanizes the world are more likely to have automation fears. These data suggest that those who have concerns that technologies will dehumanize the world, also fear for the impact of 
such technologies in the workplace. Thus, the data suggest that the respondents who fear automation in the workplace may actually fear a world in which the human is replaced by machines, meaning the world will be designed around machines, rather than people. This mindset is consistent with what other authors have speculated about (see, for example; Bhattacharyya, \& Nair, 2019; Danaher, 2019; Leonhard, 2016) and others have found empirical evidence for (Tussyadiah, Zach \& Wang, 2017). Also, it seems that those who consider themselves to be professional are less likely to fear automation, supporting the findings of others (Nikou \& Economides, 2017) to show that self-perception plays a role in influencing acceptance and fears of new technologies. That peer-pressure plays a role in influencing fears of automation is consistent with previous research (Madigan et al., 2017), showing that peerpressure is a factor influencing perceptions of technologies. The findings also show that a key characteristic of a person's job can influence a person's fear of automation, something consistent with the findings of Coupe (2019).

In terms of solutions to automation of the workplace, this work adds to the previous literature (Ivanov, 2017; Nam, 2019; Stevens \& Marchant, 2017) by illustrating that there are different levels of support for different types of solutions among the public. First, there is strong evidence that gender plays a role in influencing preferences for solutions to the challenges of automation of the workplace. Females seem much more engaged in various solutions to the challenges of automation, supporting improving of their qualifications (individual solution), various corporate solutions, and more governmental intervention via training, taxation, and other methods to cushion workers from the impact of automation of the workplace. This finding is consistent with the findings of Nam (2019), suggesting that gender plays a noteworthy role in terms of preferences for policies to deal with the incorporation of new technologies into the workplace. Unsurprisingly, those who are less wealthy seem to be more in favour of government/intervention than others. However, there is some indication that those in the capital city are less likely to support solutions that involve the government creating jobs or subsidizing companies for creating jobs.

The paradox of the findings is that gender plays little or no role in terms of conditioning a fear of automation but is useful in terms of explaining preferences for solutions to automation. This is one of the interesting findings, since while it seems that gender plays a significant role in terms of how one experiences the workplace, it seems to play little or no role in terms of how an individual processes the threat of automation in the workplace. However, when faced with 
policy choices with regards to how automation of the workplace should be dealt with, males and females seem to have very different opinions of which policies should be followed. What is also interesting or enigmatic about the findings with regards to gender is that the data show that males and females generally have a statistically different view on many questions with regards to automation in the workplace, except when it comes to automation fears. So, the data seem to show that gender seems to matter in most things tested for, except automation fears.

\section{Conclusion}

\subsection{Contribution}

This paper aimed at evaluating the drivers and the solutions to automation fears by using Bulgaria as a case study country. Its theoretical contributions are several. First, the automation fears are assessed for a transition economy (Bulgaria), unlike the previous studies that concentrated on developed countries. Hence, our research extends the cultural and geographic scope of studies on automation fears. Second, the paper elaborates on seven groups of factors that (may) influence the automation fears, namely: general perceptions of automation technologies (perceived benefits and dehumanization), the characteristics of automation technologies as production factors compared to human employees (perceived advantages and disadvantages), demographic characteristics of respondents (education, age, gender, place of living, and perceived economic well-being), their self-perception (innovativeness, technological skills, and professionalism), job characteristics (job automatability and job level), work experience of respondents (number of years on a particular job position and total work experience), and social influence. Therefore, the paper considers factors that are associated to human employees, to automation technologies, to job positions, and to external social pressure. The findings revealed that the automation fear was positively associated to the perceived dehumanisation effect of automation on society, job automatability, and social influence, and negatively associated to the professionalism. Third, the paper discusses respondents' support to various solutions to automation fears on individual, corporate and social level, and identifies the factors that shape it, namely gender, perceived economic wellbeing, and place of living.

\subsection{Managerial implications}

From a managerial point of view, findings reveal that respondents have very low fear of automation (Table 2) that is shaped mostly by perceived dehumanisation effect of automation technologies, social influence, perceived professionalism, and job automatability (Table 6). 
However, that result should not lead managers to adopt a false sense of complacency and they should be responsible to their employees. They should organise meetings with employees in the case that automation technologies are to be introduced in their companies in order to address their potential fears of losing their jobs. They need to emphasise the positive impacts of automation on eliminating operational bottlenecks and providing more time to human employees to focus on creative and revenue generating activities (Schlögl et al., 2019). Managers should realize that their employees are not blank slates and there is evidence that citizens have preferences for solutions to the challenges of automation (Nam, 2019).

Companies need to pay special attention to those workers who are most at risk of being replaced by automation by providing them free requalification programs (Hancock, 2015; Harayama, 2017). They could also introduce work sharing and reduced working hours in order to keep some of the displaced human employees (Table 7). It is important, that managers keep their workers informed about strategic decisions and plans about investing in robots, artificial intelligence and automation technologies, and involve them into the decision-making process because workers should be prepared in advance about their professional future in the current company. Employees should support the decisions regarding the adoption of ATs, because otherwise they may boycott their introduction and effective and efficient usage. Managers need to explain benefits that automation technologies provide and how they eliminate a lot of tedious work with real examples and demonstration with the manufacturer of these automation equipment. Meetings could be organized between companies already using ATs to exchange experience on how to work with employees who are potentially at risk of replacement. Additionally, companies should enrich the job positions with tasks that are more difficult to automate but also more meaningful to human employees, hence indirectly decreasing the fear of employees of losing their jobs due to automation technologies.

In terms of communications, the findings suggest that the attitudes towards the dehumanisation effect of automation technologies play a large role in shaping a person's automation fears rather than demographics. Therefore, the messages to make it easier to promote ATs need not be gendered or crafted for a specific demographic group but should be used to communicate to a group defined by attitudes. Companies that produce and implement ATs need to emphasize on the social benefits of automation as a way to mitigate the perceived dehumanization effect of ATs, which may contribute to decreased automation fears as well. 
In addition, there are engineering implications, since the philosophical concepts with regards to the "ironies of automation," (Bainbridge 1983) are still relevant. While many employees may not really fear being replaced by automation, they may actually fear having more responsibilities and less support, since the concern for the human may take a backseat to concerns with the simple automation of a process. So, while the findings indicate that there are clusters of respondents with different levels of fear of automation, some to the fear may be based on that fact that those human jobs remaining may be much more complicated and have less support than a job that is less automated. Therefore, AT producers need to make their products understandable to the employees who use them in order to address their concerns (Bhargava, Bester \& Bolton, 2020) - e.g. hotel revenue managers have to understand how an automated pricing system produces a demand forecast. Obviously, the information about the exact way the ATs operate is a trade secret, but users may need to be familiar with their general principles of their operation. Furthermore, AT producers have to provide training and technical support to adopters of their products. Collaboration between AT producers and users in the design of ATs may be beneficial as well.

\subsection{Policy implications}

Research findings indicate that Bulgarians support mostly individual solutions to automation fears, rather than social ones - they would prefer to improve their qualification in order to perform on their current jobs better than automation technologies, or to learn how to use them more productively rather than relying on some social benefits provided by the government (Table 7). However, confronting automation fear is the destiny of the government, but the tools in their arsenal have different efficiency. Policy makers need to invest in education in order to prepare human employees to work in a robonomic society where most of goods and services are provided through ATs (Ivanov, 2017). They should also require that companies evaluate and publicly announce the impact of automation technologies on jobs. Taxing ATs, although a politically correct strategy that may attract large populist vote, will not be a viable strategy for mitigating automation fears, due to difficulties in providing a workable legal definition of such technologies. Additionally, despite the fact that basic income does not seem to be supported by respondents at the moment, probably due to the low unemployment rate in the country $(3.7 \%$ for July-September 2019, NSI, 2019c), this option might be on the table in a decade or so when the impacts of automation technologies on the labour market are stronger, especially if newer more sophisticated autonomous robots cause massive technological unemployment. Therefore, the advances in automation technologies, their improved technical capabilities, lower costs, and 
wide adoption by manufacturing and service companies in the future may force governments to search for creative solutions to mitigate not only automation fears, but actual technological unemployment as well.

\subsection{Limitations}

This paper is not without limitations. First, the sample includes only respondents from Bulgaria; hence, the results are generalisable for this cultural context only. Second, despite authors' efforts in distributing the link to social media groups with potential respondents with various demographic characteristics, the shares of respondents with low level of education and incomes, and above 60 years old remained low. Third, data were collected before the COVID-19 pandemic and it is possible that the perceptions of respondents towards automation technologies have changed.

\subsection{Future research directions}

Future research may focus on overcoming some of the limitations of this paper, e.g. by replicating the study in other cultural and geographic context. More specifically, a global longitudinal study on automation fears may be implemented that would allow the comparison of automation fears across cultures and their changes in time. Additionally, research can investigate the role of some other job characteristics (e.g. emotional, intellectual, of physical labour dominating in the job position) in respondents' fear of automation, since demographics seems to have limited explanatory power in the analysis. Furthermore, future research may shed insights on the perspectives on employers and policy makers at local, national, and international levels in regard to the solutions to automation fears, so that more can be known about how employees, employers, and government views solutions to automation fears. Research can also investigate whether the official government policies reflect the automation fears of local populations and the role of political ideologies in mitigating the negative impacts of automation. Finally, research can be directed on the ways to finances and evaluation of the efficiency of the various strategies to mitigate automation fears.

\section{References:}

Arntz, M., Gregory, T., \& Zierahn, U. (2017). Revisiting the risk of automation. Economics Letters, 159, 157-160. 
Autor, D., \& Salomons, A. (2018). Is automation labor-displacing? Productivity growth, employment, and the labor share (No. w24871). National Bureau of Economic Research. Retrieved from https://www.nber.org/papers/w24871.pdf

Bainbridge, L. (1983). Ironies of automation. Automatica, 19(6), 775-779.

Barrat, J. (2013). Our final invention: Artificial intelligence and the end of the human era. New York: Macmillan.

Baxter, G., Rooksby, J., Wang, Y., \& Khajeh-Hosseini, A. (2012). The ironies of automation: still going strong at 30?. In Turner, P., Turner, S., \& McGregor, I. (Eds.) Proceedings of the 30th European Conference on Cognitive Ergonomics, 28-31 August 2012, Edinburgh, UK (pp. 65-71).

Berg, A., Buffie, E. F., \& Zanna, L. F. (2018). Should we fear the robot revolution? (The correct answer is yes). Journal of Monetary Economics, 97, 117-148. https://doi.org/10.1016/j.jmoneco.2018.05.014

Bhargava, A., Bester, M., \& Bolton, L. (2020). Employees' Perceptions of the Implementation of Robotics, Artificial Intelligence, and Automation (RAIA) on Job Satisfaction, Job Security, and Employability. Journal of Technology in Behavioral Science, 1-8. doi: https://doi.org/10.1007/s41347-020-00153-8

Bhatnagar, N. (2020). Role of robotic process automation in pharmaceutical industries. In: Hassanien A., Azar A., Gaber T., Bhatnagar R., F. Tolba M. (Eds) The International Conference on Advanced Machine Learning Technologies and Applications (AMLTA2019). AMLTA 2019. Cairo, Egypt, March 28-30, 2019. Advances in Intelligent Systems and Computing, vol 921. Cham: Springer. pp 497-504

Bhattacharyya, S., \& Nair, S. (2019). Explicating the future of work: perspectives from India. Journal of Management Development, 38(3), 175-194. https://doi.org/10.1108/JMD01-2019-0032

Bhaumik, A. (2018). From AI to Robotics: Mobile, Social, and Sentient Robots. Boca Raton, FL: CRC Press.

Bossers, A., Kernaghan, J., Hodgins, L., Merla, L., O'Connor, C., \& Van Kessel, M. (1999). Defining and developing professionalism. Canadian Journal of Occupational Therapy, 66(3), 116-121.

Brynjolffson, E., \& McAfee, A. (2015). Will Humans Go the Way of Horses? Labor in the Second Machine Age. Foreign Affairs, 94(4), 8-14.

Brynjolfsson, E., \& McAfee, A. (2014). The second machine age: Work, progress, and prosperity in a time of brilliant technologies. WW Norton \& Company. 
Bughin, J., Hazan, E., Lund, S., Dahlstom, P., Wiesinger, A., \& Subramaniam, A. (2018). Skill shift: Automation and the future of the workforce. Discussion Paper May 2018, McKinsey \& Company. Retrieved from https://www.mckinsey.com/featuredinsights/future-of-work/skill-shift-automation-and-the-future-of-the-workforce

Buhalis D., \& Yen E.C.S. (2020). Exploring the Use of Chatbots in Hotels: Technology Providers' Perspective. In Neidhardt J., Wörndl W. (eds) Information and Communication Technologies in Tourism 2020. Cham: Springer.

Chan, E. P. (2017). Machine trading: Deploying computer algorithms to conquer the markets. Hoboken, NJ: John Wiley \& Sons.

Chen, N. H., \& Huang, S. C. T. (2016). Domestic technology adoption: comparison of innovation adoption models and moderators. Human Factors and Ergonomics in Manufacturing \& Service Industries, 26(2), 177-190.

Crews, J. (2016). Robonomics: Prepare today for the jobless economy of tomorrow. CreateSpace Independent Publishing Platform.

Cubero, S. (Eds) (2007). Industrial robotics: theory, modelling and control. Mammendorf: pro literature Verlag Robert Mayer-Scholz.

Coupe, T. (2019). Automation, job characteristics and job insecurity. International Journal of Manpower 40(7), 1288-1304.

Dahlin, E. (2019). Are robots stealing our jobs? Socius: Sociological Research for a Dynamic World, 5, 1-14. DOI: https://doi.org/10.1177/2378023119846249

Danaher, J. (2019). Automation and Utopia: Human Flourishing in a World without Work. Cambridge, MA: Harvard University Press.

DeCanio, S. J. (2016). Robots and humans-complements or substitutes? Journal of Macroeconomics, 49, 280-291.

Decker, M., Fischer, M., \& Ott, I. (2017). Service Robotics and Human Labor: A first technology assessment of substitution and cooperation. Robotics and Autonomous Systems, 87, 348-354.

Delgado, J. M. D., Oyedele, L., Ajayi, A., Akanbi, L., Akinade, O., Bilal, M., \& Owolabi, H. (2019). Robotics and automated systems in construction: Understanding industryspecific challenges for adoption. Journal of Building Engineering, 26, 100868. Doi: https://doi.org/10.1016/j.jobe.2019.100868

del Rio, J. S., Moctezuma, D., Conde, C., de Diego, I. M., \& Cabello, E. (2016). Automated border control e-gates and facial recognition systems. Computers \& Security, 62, 49-72. 
Dengler, K., \& Matthes, B. (2018). The impacts of digital transformation on the labour market: Substitution potentials of occupations in Germany. Technological Forecasting and Social Change, 137, 304-316. doi: 10.1016/j.techfore.2018.09.024

Dencker, J. C. (2008). Corporate restructuring and sex differences in managerial promotion. American Sociological Review, 73(3), 455-476. Doi: https://doi.org/10.1177/000312240807300305

Dimitrova, T. (2019). The lack of employees and of e-government hinders business [in Bulgarian language]. Retrieved on $19^{\text {th }}$ December 2019 from https://www.dnevnik.bg/biznes/2019/12/16/4006507_lipsata_na_rabotna_ruka_i_na_e lektronno_pravitelstvo/

Dolnicar, S., Grün, B., Leisch, F., \& Schmidt, K. (2014). Required Sample Sizes for DataDriven Market Segmentation Analyses in Tourism. Journal of Travel Research, 53(3), 296-306. https://doi.org/10.1177/0047287513496475

Drexler, K. E. (2013). Radical abundance: How a revolution in nanotechnology will change civilization. New York: Public Affairs.

Driessen, C., \& Heutinck, L. F. M. (2015). Cows desiring to be milked? Milking robots and the co-evolution of ethics and technology on Dutch dairy farms. Agriculture and Human Values, 32(1), 3-20.

Dunis, C. L., Middleton, P. W., Karathanasopolous, A., \& Theofilatos, K. A. (Eds.). (2017). Artificial Intelligence in Financial Markets: Cutting Edge Applications for Risk Management, Portfolio Optimization and Economics. London: Palgrave Macmillan.

Ernst, E., Merola, R., \& Samaan, D. (2019). Economics of Artificial Intelligence: Implications for the Future of Work. IZA Journal of Labor Policy, 9(1), 20190004. doi: https://doi.org/10.2478/izajolp-2019-0004

Ertel, W. (2017). Introduction to artificial intelligence. $2^{\text {nd }}$ ed. Cham: Springer.

Feldmann, H. (2013). Technological unemployment in industrial countries. Journal of Evolutionary Economics, 23(5), 1099-1126. doi:10.1007/s00191-013-0308-6

Fiaidhi, J., Mohammed, S., \& Mohammed, S. (2018). The robotization of extreme automation: The balance between fear and courage. IT Professional, 20(6), 87-93. Doi: $\underline{10.1109 / M I T P .2018 .2876979}$

Frank, M., Roehring, P., \& Pring, B. (2017). What to do when machines do everything: How to get ahead in a world of AI, algorithms, bots and big data. Hoboken, NJ: John Wiley \& Sons, Inc. 
Frank, M. R., Autor, D., Bessen, J. E., Brynjolfsson, E., Cebrian, M., Deming, D. J., Feldman, M., Groh, M., Lobo, J., Moro, E., Wang, D., Youn, H., \& Rahwan, I. (2019). Toward understanding the impact of artificial intelligence on labor. Proceedings of the National Academy of Sciences, 116(14), 6531-6539. https://doi.org/10.1073/pnas.1900949116

Frey, C. B. (2019). The technology trap: Capital, labor, and power in the age of automation. Princeton \& Oxford: Princeton University Press.

Frey, C. B., \& Osborne, M. A. (2017). The future of employment: how susceptible are jobs to computerisation? Technological Forecasting and Social Change, 114, 254-280.

Hancock, M. (2015) Artificial Intelligence: Opportunities and implications for the future of decision making. Government Office for Science. https://assets.publishing.service.gov.uk/government/uploads/system/uploads/attachme nt_data/file/566075/gs-16-19-artificial-intelligence-ai-report.pdf

Harayama, Y. (2017) Report on artificial intelligence and human society. Advisory Board on AI and Human Society, Council for Science, Technology and Innovation, the Cabinet Office of Japan. https://www8.cao.go.jp/cstp/tyousakai/ai/summary/aisociety_en.pdf

Hill, J., Ford, W. R., \& Farreras, I. G. (2015). Real conversations with artificial intelligence: A comparison between human-human online conversations and human-chatbot conversations. Computers in Human Behavior, 49, 245-250.

Huang, M. H., \& Rust, R. T. (2018). Artificial intelligence in service. Journal of Service Research, 21(2), 155-172.

Hudson, J., Orviska, M., \& Hunady, J. (2017) People's attitudes to robots in caring for the elderly. International Journal of Social Robotics, 9(2), 199-210.

Hultin, M., \& Szulkin, R. (1999). Wages and unequal access to organizational power: An empirical test of gender discrimination. Administrative Science Quarterly, 44(3), 453472.

Hurd, C. C. (1958). The social problem of automation. In Proceedings of the Western Joint Computer Conference: Contrasts in Computers, IRE-AIEE-ACM 1958, Los Angeles, US, 6-8 May 1958, pp. 13-16. Doi; $10.1145 / 1457769.1457774$

International Federation of Robotics (2019). Executive Summary World Robotics 2019 Industrial Robots. Retrieved on $26^{\text {th }}$ November 2019 from https://ifr.org/downloads/press2018/Executive\%20Summary\%20WR\%202019\%20Ind ustrial\%20Robots.pdf

International Labour Organization /ILO/ (2019a). Employment by sex and economic activity ILO modelled estimates, November 2018 (thousands) - Annual. Retrieved on $22^{\text {nd }}$ 
December

https://www.ilo.org/shinyapps/bulkexplorer0/?lang=en\&segment=indicator\&id=EMP _2EMP_SEX_ECO_NB_A

International Labour Organization /ILO/ (2019b). SDG Indicator 5.5.2 - Female share of employment in managerial positions (\%) Annual. Retrieved on 22 ${ }^{\text {nd }}$ December 2019 from

https://www.ilo.org/shinyapps/bulkexplorer38/?lang=en\&segment=indicator\&id=SDG _0552_OCU_RT_A

Ionescu, L. (2019). Should governments tax companies' use of robots? Automated workers, technological unemployment, and wage inequality. Economics, Management, and Financial Markets, 14(2), 64-69.

Ivanov, S. (2020). The impact of automation on tourism and hospitality jobs. Information Technology \& Tourism 22(2), 205-215. https://doi.org/10.1007/s40558-020-00175-1

Ivanov, S. (2019). Ultimate transformation: How will automation technologies disrupt the travel, tourism and hospitality industries? Zeitschrift für Tourismuswissenschaft 11(1), $25-43$.

Ivanov, S. (2017). Robonomics - principles, benefits, challenges, solutions. Yearbook of Varna University of Management, 10, 283-293.

Ivanov, S., \& Webster, C. (Eds.) (2019a). Robots, Artificial Intelligence and Service Automation in Travel, Tourism and Hospitality. Bingley, UK: Emerald Publishing.

Ivanov, S., \& Webster, C. (2019b). Economic Fundamentals of the Use of Robots, Artificial Intelligence and Service Automation in Travel, Tourism and Hospitality. In Ivanov, S., \& Webster, C. (Eds.) (2019). Robots, Artificial Intelligence and Service Automation in Travel, Tourism and Hospitality. ISBN: 978-1-78756-688-0. Emerald Publishing, pp. 39-55.

Ivanov, S., Webster, C. \& Garenko, A. (2018). Young Russian adults' attitudes towards the potential use of robots in hotels. Technology in Society 55, 24-32, https://doi.org/10.1016/j.techsoc.2018.06.004

Ivanov, S., Webster, C. \& Seyyedi, P. (2018). Consumers' attitudes towards the introduction of robots in accommodation establishments. Tourism 63(3), 302-317.

Johe, M. H., \& Bhullar, N. (2016). To buy or not to buy: The roles of self-identity, attitudes, perceived behavioral control and norms in organic consumerism. Ecological Economics, 128, 99-105. Doi: https://doi.org/10.1016/j.ecolecon.2016.02.019 
Jones, S. E. (2006). Against technology: from the Luddites to Neo-Luddism. New York and London: Routledge.

Katz, J.E., \& Halpern, D. (2014) Attitudes towards robots suitability for various jobs as affected robot appearance. Behaviour and Information Technology, 33(9), 941-953.

Kabugo, J. C., Jämsä-Jounela, S. L., Schiemann, R., \& Binder, C. (2020). Industry 4.0 based process data analytics platform: A waste-to-energy plant case study. International Journal of Electrical Power \& Energy Systems, 115, 105508.

Keynes, J. (1930/1963). Economic possibilities for our grandchildren. In J. M. Keynes (1963). Essays in Persuasion. New York: W.W.Norton \& Co., pp. 358-373.

Kolnhofer-Derecskei, A., Reicher, R. Z., \& Szeghegyi, A. (2017). The X and Y generations' characteristics comparison. Acta Polytechnica Hungarica, 14(8), 107-125.

Kral, P., Janoskova, K., Podhorska, I., Pera, A., \& Neguriţă, O. (2019). The automatability of male and female jobs: technological unemployment, skill shift, and precarious work. Journal of Research in Gender Studies, 9(1), 146-152.

LaGrandeur, K. and Hughes, J. J. (Eds.) (2017). Surviving the Machine Age. Intelligent Technology and the Transformation of Human Work. London: Palgrave Macmillan.

Leonhard, G. (2016). Technology vs. Humanity. Fast Future Publishing.

Madigan, R., Louw, T., Wilbrink, M., Schieben, A., \& Merat, N. (2017). What influences the decision to use automated public transport? Using UTAUT to understand public acceptance of automated road transport systems. Transportation Research Part F: Traffic Psychology and Behaviour, 50, 55-64.

Maurer, M., Gerdes, J. C., Lenz, B., \& Winner, H. (Eds.) (2016). Autonomous driving: technical, legal and social aspects. Berlin, Heidelberg: Springer Open.

McClure, P. K. (2018). "You're fired," says the robot: The rise of automation in the workplace, technophobes, and fears of unemployment. Social Science Computer Review, 36(2), 139-156. https://doi.org/10.1177/0894439317698637

McDonough, B., \& Bustillos Morales, J. (2020). Universal basic income. Oxon and New York: Routledge.

Miller, M. R., \& Miller, R. (2017). Robots and Robotics: Principles, Systems, and Industrial Applications. New York: McGraw-Hill Education.

Milosavljević, M., \& Vobič, I. (2019). 'Our task is to demystify fears': Analysing newsroom management of automation in journalism. Journalism (forthcoming), https://doi.org/10.1177/1464884919861598. 
Morikawa, M. (2017). Who are afraid of losing their jobs to artificial intelligence and robots? Evidence from a survey. RIETI Discussion Paper Series 17-E-069. Retrieved from http://hermes-ir.lib.hit-u.ac.jp/rs/bitstream/10086/30381/1/DP17-007.pdf

Moutsatsou, P., Ochs, J., Schmitt, R. H., Hewitt, C. J., \& Hanga, M. P. (2019). Automation in cell and gene therapy manufacturing: from past to future. Biotechnology Letters 41, 1245-1253. doi:10.1007/s10529-019-02732-z

Nam, T. (2019). Citizen attitudes about job replacement by robotic automation. Futures, 109, 39-49. doi: 10.1016/j.futures.2019.04.005

National Statistics Institute /NSI/ (2019a). GDP by Production approach. Retrieved $26^{\text {th }}$ November 2019 from https://www.nsi.bg/bg/node/2206

National Statistics Institute /NSI/ (2019b). Population and Demographic Processes in 2018. Retrieved $26^{\text {th }}$ November 2019 from https://www.nsi.bg/bg/node/17132

National Statistics Institute /NSI/ (2019c). Main Labour Force Survey Results for the Third Quarter of 2019. Retrieved 26 ${ }^{\text {th }}$ November 2019 from https://www.nsi.bg/bg/node/17676

National Statistics Institute /NSI/ (2019d). Employees under labour contract by economic activities (A21) and sex (2008-2018). Retrieved 22 ${ }^{\text {nd }}$ December 2019 from https://infostat.nsi.bg/infostat/pages/reports/result.jsf?x_2=320

Neapolitan, R. E., \& Jiang, X. (2018). Artificial intelligence: With an introduction to machine learning. $2^{\text {nd }}$ ed. Boca Raton: CRC Press.

New York Post (November 11, 2019) American robots lose jobs to Asian robots as Adidas shifts manufacturing. Retrieved $12^{\text {th }} \quad$ November 2019 from https://nypost.com/2019/11/11/american-robots-lose-jobs-to-asian-robots-as-adidasshifts-manufacturing/

Nikou, S. A., \& Economides, A. A. (2017). Mobile-Based Assessment: Integrating acceptance and motivational factors into a combined model of Self-Determination Theory and Technology Acceptance. Computers in Human Behavior, 68, 83-95. Doi: https://doi.org/10.1016/j.chb.2016.11.020

Nørskov, M. (2016). Social Robots: Boundaries, Potential, Challenges. London and New York: Routledge.

Parasuraman, A., \& Colby, C. L. (2015). An updated and streamlined technology readiness index: TRI 2.0. Journal of service research, 18(1), 59-74. 
Pochwatko, G., Giger, J.-C., Różańska-Walczuk, M., Świdrak, J., Kukiełka, K., Możaryn, J., \& Piçarra, N. (2015). Polish version of the negative attitude toward robots scale (NARSPL) Journal of Automation, Mobile Robotics and Intelligent Systems, 9(3), 65-72.

Postel-Vinay, F. (2002). The dynamics of technological unemployment. International Economic Review, 43(3), 737-760. Doi: https://doi.org/10.1111/1468-2354.t01-1-00033 Rago, L. J. (1965). Tooling Up for Automation Hampered by Myths and Fears. Business \& Society, 5(2), 33-36. Doi: https://doi.org/10.1177/000765036500500206

Reich-Stiebert, N., \& Eyssel, F. (2015). Learning with educational companion robots? Toward attitudes on education robots, predictors of attitudes, and application potentials for education robots. International Journal of Social Robotics, 7(5), 875-888.

Remus, D. \& Levy, F. (2015) Can robots be lawyers? Computers, lawyers, and the practice of law. Retrieved from: http://ssrn.com/abstract=2701092

Ross, L. T., Fardo, S. W., \& Walach, M. F. (2018). Industrial Robotics Fundamentals: Theory and Applications. Tinley Park, IL: Goodheart-Willcox Co.

Russell, S. J., \& Norvig, P. (2016). Artificial intelligence: a modern approach. Harlow: Pearson Education Limited.

Schiffman, L., O’Cass, A., Paladino, A., \& Carlson, J. (2014). Consumer behaviour (6 ${ }^{\text {th }}$ ed.). Frenchs Forest, NSW: Pearson Australia.

Schlögl, S., Postulka, C., Bernsteiner, R., and Ploder, C. (2019). Artificial Intelligence Tool Penetration in Business: Adoption, Challenges and Fears. In: Uden, L., Ting, I. H., Corchado, J. (Eds.) Knowledge Management in Organizations. KMO 2019. Communications in Computer and Information Science, Vol. 1027. Cham: Springer, pp. 259-270.

Sheahen, A. (2012). Basic income guarantee: your right to economic security. New York: Palgrave Macmillan.

Singh, A., Ramasubramanian, K., \& Shivam, S. (2019). Building an enterprise chatbot: Work with protected enterprise data using open source frameworks. New York: Apress.

Slaughter, D. C., Giles, D. K., \& Downey, D. (2008). Autonomous robotic weed control systems: A review. Computers and electronics in agriculture, 61(1), 63-78.

Spencer, D. (2018). Fear and hope in an age of mass automation: Debating the future of work. New Technology, Work, and Employment, 33(1), 1-12. Doi: https://doi.org/10.1111/ntwe.12105

Stevens, Y. A., \& Marchant, G. E. (2017). Policy solutions to technological unemployment. In LaGrandeur, K. and Hughes, J. J. (Eds.) (2017). Surviving the Machine Age. Intelligent 
Technology and the Transformation of Human Work. London: Palgrave Macmillan (pp. 117-130).

Stimmer, H. (1984). Technology - a curse or a blessing? [Technik - Fluch oder Segen?]. Österreichische Zeitschrift für Elektrizitätswirtschaft, 37(1), 1-7.

Strauch, B. (2017). Ironies of automation: Still unresolved after all these years. IEEE Transactions on Human-Machine Systems, 48(5), 419-433.

Stubbs, A. (2017). Automation, Artificial Intelligence, and the God/Useless Divide. Perspectives on Global Development and Technology, 16(6), 700-716. Doi: https://doi.org/10.1163/15691497-12341457

Talwar, R., Wells, S., Whittington, Al, Koury, A., \& Romero, M. (2017). The future reinvented. Reimagining life, society, and business. Fast Future Publishing.

Tonkova, E. (2016). Automated marketing and the need to revise traditional practices. Journal of Emerging Trends in Marketing and Management, 1(1), 167-174.

Tussyadiah, I. P., Zach, F. K. \& Wang, J. (2017). Attitudes Toward Autonomous on Demand Mobility System: The Case of Self-Driving Taxi. In Schegg, R. \& Strangl, B. (Eds.) Information and Communication Technologies in Tourism 2017. Proceedings of the International Conference in Rome, Italy, January 24-26, 2017, pp. 755-766.

Venkatesh, V., Thong, J. Y., \& Xu, X. (2012). Consumer acceptance and use of information technology: extending the unified theory of acceptance and use of technology. MIS quarterly, 36(1), 157-178.

Walsh, T. (2018). Expert and non-expert opinion about technological unemployment. International Journal of Automation and Computing, 15(5), 637-642. https://doi.org/10.1007/s11633-018-1127-x

Webster, C., \& Ivanov, S. (2020). Robotics, artificial intelligence, and the evolving nature of work. In George, B., \& Paul, J. (Eds.). Digital Transformation in Business and Society Theory and Cases, Palgrave-MacMillan, pp. 127-143.

Webster, C. \& Ivanov, S. (2019) What should robots do in hospitality and tourism? The influence of attitudes and demographics. Proceedings of AIRSI 2019 in Zaragoza, Spain, 8-9 July, 2019. Pp. 55-71.

Wiedmann, K. P., Hennigs, N., Varelmann, D., \& Reeh, M. O. (2010). Determinants of consumers' perceived trust in IT-ecosystems. Journal of Theoretical and Applied Electronic Commerce Research,5(2), 137-154. DOI: 10.4067/S071818762010000200009 
Wirtz, J., Patterson, P., Kunz, W., Gruber, T., Lu, V. N., Paluch, S., \& Martins, A. (2018). Brave New World: Service Robots in the Frontline. Journal of Service Management, 29(5), 907-931.

Wurman, P. R., D’Andrea, R., \& Mountz, M. (2008). Coordinating hundreds of cooperative, autonomous vehicles in warehouses. AI Magazine, 29(1), 9-19. 
Figure 1. Factors influencing the fear of automation

Note: + positive relationship, - negative relationship

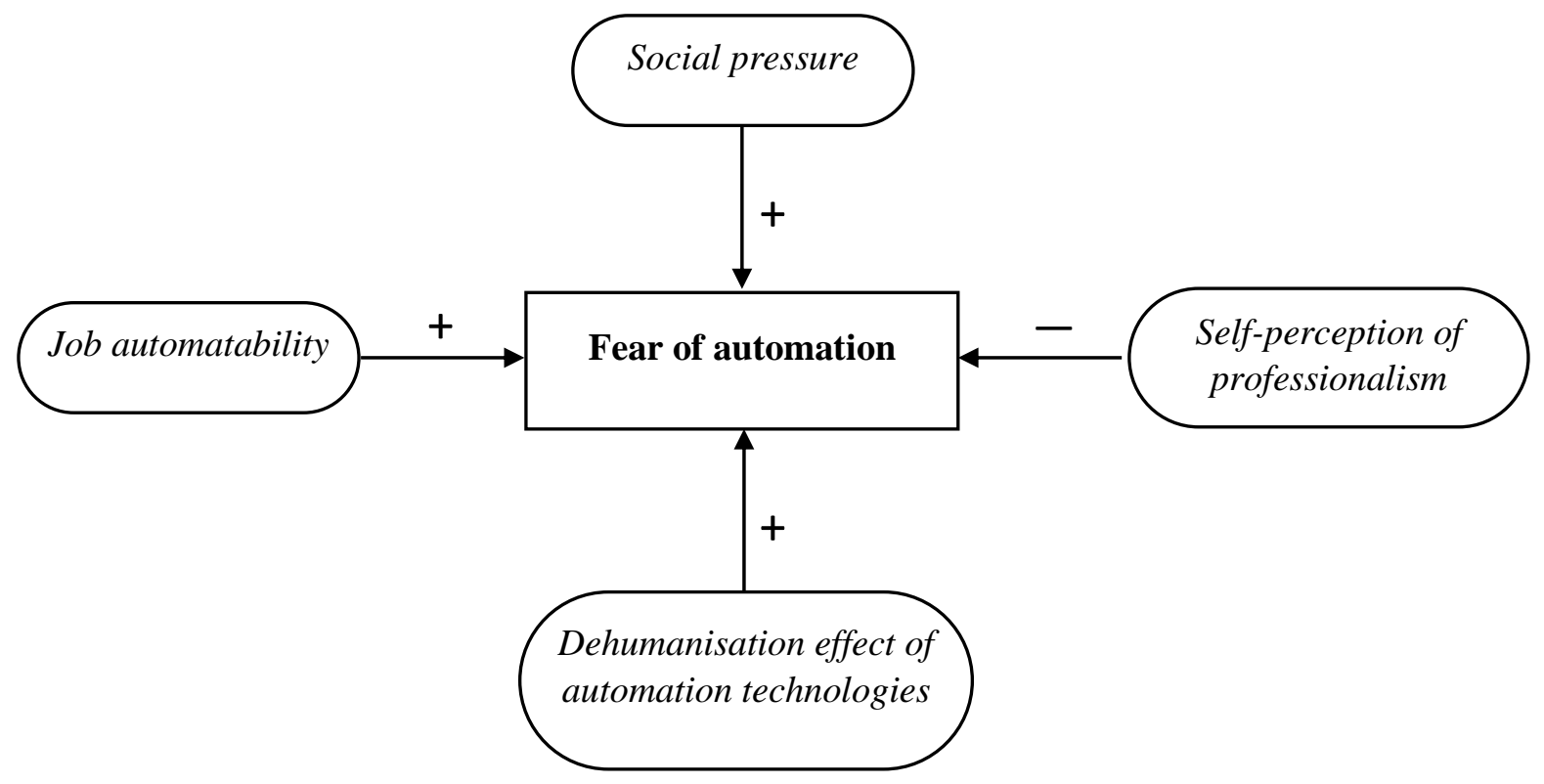


Table 1. Sample characteristics

\begin{tabular}{|c|c|c|c|}
\hline Variable & Value & $\begin{array}{l}\text { Number of } \\
\text { respondents }\end{array}$ & Percent \\
\hline \multirow[t]{3}{*}{ Gender } & Female & 212 & 42.2 \\
\hline & Male & 288 & 57.4 \\
\hline & Prefer not to say & 2 & 0.4 \\
\hline \multirow[t]{5}{*}{ Age } & $18-30$ & 134 & 26.7 \\
\hline & $31-40$ & 218 & 43.4 \\
\hline & $41-50$ & 118 & 23.5 \\
\hline & $51-60$ & 27 & 5.4 \\
\hline & $61+$ & 5 & 1.0 \\
\hline \multirow[t]{5}{*}{ Education } & Secondary / high school or lower & 65 & 12.9 \\
\hline & 3-year Bachelor/Specialist & 37 & 7.4 \\
\hline & 4-year Bachelor & 120 & 23.9 \\
\hline & Master & 251 & 50.0 \\
\hline & Doctorate & 29 & 5.8 \\
\hline \multirow{7}{*}{$\begin{array}{l}\text { Perceived } \\
\text { economic } \\
\text { wellbeing }\end{array}$} & Much less wealthy than the average for the country & 3 & 0.6 \\
\hline & Less wealthy than the average for the country & 14 & 2.8 \\
\hline & Slightly less wealthy than the average for the country & 31 & 6.2 \\
\hline & About the average for the country & 147 & 29.3 \\
\hline & Slightly more wealthy than the average for the country & 181 & 36.1 \\
\hline & More wealthy than the average for the country & 107 & 21.3 \\
\hline & Much more wealthy than the average for the country & 19 & 3.8 \\
\hline \multirow[t]{7}{*}{ Place of living } & Sofia & 278 & 55.4 \\
\hline & Living in Bulgaria but outside Sofia, including: & 196 & 39.0 \\
\hline & City with 100000 - 999999 inhabitants & 125 & 24.9 \\
\hline & Town with 10000 - 99999 inhabitants & 58 & 11.6 \\
\hline & Town with less than 10000 inhabitants & 4 & 0.8 \\
\hline & Village & 9 & 1.8 \\
\hline & Bulgarian citizens who live abroad & 28 & 5.6 \\
\hline Total & & 502 & 100.0 \\
\hline
\end{tabular}




\begin{tabular}{|c|c|c|c|c|c|c|c|c|c|c|}
\hline \multirow[t]{2}{*}{ Statements } & \multirow[t]{2}{*}{ Mean } & \multirow{2}{*}{$\begin{array}{l}\text { St. } \\
\text { dev. }\end{array}$} & \multicolumn{2}{|c|}{ Mann-Whitney $U$-test } & \multicolumn{6}{|c|}{ Kruskal-Wallis $\chi 2$-test } \\
\hline & & & Gender & Cluster & Age & Education & Wellbeing & $\begin{array}{l}\text { Work } \\
\text { experience }\end{array}$ & Job level & $\begin{array}{l}\text { Place of } \\
\text { living }\end{array}$ \\
\hline \multicolumn{11}{|l|}{ Attitude } \\
\hline $\begin{array}{l}\text { What is your personal attitude towards automation technologies in } \\
\text { general? }\end{array}$ & 6.17 & 0.958 & $25745^{* * *}$ & $14252.5 * * *$ & 3.198 & 0.194 & 5.804 & 1.201 & 7.131 & $7.000 *$ \\
\hline $\begin{array}{l}\text { How do you evaluate the current impact of automation technologies } \\
\text { on your life? }\end{array}$ & 5.95 & 1.112 & $26806.5^{*}$ & $16726.5 * * *$ & 5.312 & 2.938 & $20.840 * * *$ & 1.254 & $8.345^{*}$ & 3.813 \\
\hline $\begin{array}{l}\text { How do you evaluate the impact of automation technologies on } \\
\text { your life would be in } 5 \text { years? }\end{array}$ & 5.94 & 1.219 & $27239 *$ & $14387.5^{* * *}$ & 6.508 & 4.832 & $15.223 * * *$ & 1.936 & 3.813 & 0.621 \\
\hline \multicolumn{11}{|l|}{ Perceived benefits } \\
\hline $\begin{array}{l}\text { Automation technologies are (will be) responsible for many of the } \\
\text { good things we enjoy in life }\end{array}$ & 5.04 & 1.474 & $23424.5^{* * *}$ & $17350.5 * *$ & 0.892 & 5.516 & $7.738^{*}$ & 0.237 & 4.854 & 2.693 \\
\hline Automation technologies (will) improve our standard of living & 5.52 & 1.368 & $25286.5 * * *$ & $13602 * * *$ & 2.151 & 3.511 & $15.015^{* * *}$ & 3.233 & 5.266 & $6.078 *$ \\
\hline Automation technologies will bring us a bright future & 4.79 & 1.504 & $25842 * *$ & $16267 * * *$ & $19.646^{* * *}$ & 8.115 & $9.343 * *$ & 7.273 & 1.966 & 3.208 \\
\hline Life is (will be) easier with automation technologies & 5.75 & 1.203 & $23536 * * *$ & $13572 * * *$ & 4.316 & 5.402 & 4.888 & 1.905 & 0.713 & $11.114 * *$ \\
\hline Automation technologies (will) make our lives more convenient & 5.99 & 1.014 & $24997 * * *$ & $15100.5 * * *$ & 5.632 & 4.278 & $13.187 * * *$ & 2.978 & 3.832 & $10.483 * *$ \\
\hline $\begin{array}{l}\text { Automation technologies (will) eliminate a lot of tedious work for } \\
\text { people }\end{array}$ & 6.04 & 1.064 & $25821.5^{* *}$ & $16015.5^{* * *}$ & $11.436^{*}$ & 3.277 & 4.592 & 7.545 & 1.307 & $11.907 * *$ \\
\hline Automation technologies (will) make people happier & 4.39 & 1.517 & $25493 * * *$ & $16689.5 * *$ & $14.131 * *$ & 3.004 & $9.023 *$ & 3.909 & 1.739 & 2.023 \\
\hline \multicolumn{11}{|l|}{ Advantages } \\
\hline $\begin{array}{l}\text { Automation technologies (will) provide more accurate information } \\
\text { than human employees }\end{array}$ & 5.49 & 1.341 & $25343 * * *$ & $18021.5^{*}$ & 7.555 & 3.467 & 5.278 & 6.131 & 4.491 & 2.889 \\
\hline $\begin{array}{l}\text { Automation technologies (will) make fewer mistakes than human } \\
\text { employees }\end{array}$ & 5.66 & 1.262 & $23133 * * *$ & $17222.5 * *$ & 4.608 & 1.643 & 4.467 & 0.936 & 0.957 & $10.182 * *$ \\
\hline $\begin{array}{l}\text { Automation technologies (will) perform faster than human } \\
\text { employees }\end{array}$ & 6.19 & 0.963 & $22771.5 * * *$ & $16482 * * *$ & $10.549 *$ & $12.959 *$ & $10.188^{* *}$ & 4.287 & 0.644 & $17.042 * * *$ \\
\hline $\begin{array}{l}\text { Automation technologies are (will be) more reliable than human } \\
\text { employees }\end{array}$ & 5.30 & 1.447 & $22160.5 * * *$ & $145135^{* * *}$ & 5.926 & 0.915 & $9.074 *$ & 4.728 & 1.574 & $7.420 *$ \\
\hline $\begin{array}{l}\text { Automation technologies (will) have higher productivity than } \\
\text { human employees }\end{array}$ & 6.11 & 1.024 & $23865.5 * * *$ & $17007.5^{* *}$ & 4.784 & 8.168 & 3.656 & 1.820 & 3.868 & $9.725 * *$ \\
\hline $\begin{array}{l}\text { Automation technologies are (will be) more cost effective than } \\
\text { human employees }\end{array}$ & 5.69 & 1.289 & 23816 *** & 18312 & 3.551 & 5.109 & 2.878 & 3.298 & 5.821 & 3.023 \\
\hline \multicolumn{11}{|l|}{ Dehumanisation } \\
\hline $\begin{array}{l}\text { Automation technologies (will) hurt our human relationships in } \\
\text { society (r) }\end{array}$ & 4.18 & 1.791 & $27150.5^{*}$ & $14264 * * *$ & 4.701 & 3.883 & 5.405 & 4.590 & 4.437 & 4.777 \\
\hline In the future, automation technologies will dominate society (r) & 2.70 & 1.405 & 28087 & 20382 & 8.306 & 2.312 & 1.258 & 10.003 & 1.198 & 1.208 \\
\hline
\end{tabular}




\begin{tabular}{|c|c|c|c|c|c|c|c|c|c|c|}
\hline \multirow[t]{2}{*}{ Statements } & \multirow[t]{2}{*}{ Mean } & \multirow{2}{*}{$\begin{array}{l}\text { St. } \\
\text { dev. }\end{array}$} & \multicolumn{2}{|c|}{ Mann-Whitney $U$-test } & \multicolumn{6}{|c|}{ Kruskal-Wallis $\chi 2$-test } \\
\hline & & & Gender & Cluster & Age & Education & Wellbeing & $\begin{array}{l}\text { Work } \\
\text { experience }\end{array}$ & Job level & $\begin{array}{l}\text { Place of } \\
\text { living }\end{array}$ \\
\hline $\begin{array}{l}\text { The overuse of automation technologies may be damaging and } \\
\text { harmful to human beings (r) }\end{array}$ & 3.85 & 1.734 & 28467.5 & $14849 * * *$ & 1.816 & 4.396 & 5137 & 0.389 & 3.606 & 4.964 \\
\hline $\begin{array}{l}\text { The overuse of automation technologies may be damaging and } \\
\text { harmful to the society as a whole (r) }\end{array}$ & 4.01 & 1.798 & $27162 *$ & $14762.5^{* * *}$ & 1.374 & 3.332 & $6.753 *$ & 4.856 & 1.935 & 2.348 \\
\hline Automation technologies (will) dehumanize the workplace (r) & 4.37 & 1.750 & 27498.5 & $13106 * * *$ & 1.218 & 2.517 & 5.968 & 5.267 & 2.396 & 5.314 \\
\hline Automation technologies (will) lead to deskilling of jobs (r) & 3.63 & 1.802 & 30108.5 & $17833 *$ & 7.403 & $20.841 * * *$ & 0.180 & 5.877 & 3.826 & 0.440 \\
\hline \multicolumn{11}{|l|}{ Disadvantages } \\
\hline $\begin{array}{l}\text { Automation technologies are (will be) able to deal with/operate } \\
\text { only in standard situations (r) }\end{array}$ & 3.31 & 1.606 & $26234 * *$ & $17465 *$ & 2.726 & 2.243 & $7.471 *$ & 4.698 & 4.964 & 2.437 \\
\hline $\begin{array}{l}\text { Automation technologies (will) lack the creativity of human } \\
\text { employees (r) }\end{array}$ & 2.58 & 1.532 & 30133 & 20413 & $9.604 *$ & 1.400 & 5.423 & 5.888 & 1.353 & 4.191 \\
\hline $\begin{array}{l}\text { Automation technologies are (will be) difficult to operate by their } \\
\text { intended users (customers, employees) (r) }\end{array}$ & 4.77 & 1.519 & $25440.5^{* * * *}$ & $14095 * * *$ & 1.975 & 2.519 & $13.564 * * *$ & 1.290 & 3.401 & $13.777 * * *$ \\
\hline $\begin{array}{l}\text { Service provided by automation technologies are (will be) less } \\
\text { interactive than services provided by human employees (r) }\end{array}$ & 4.13 & 1.617 & 29747 & $17859.5^{*}$ & 3.395 & 4.977 & 3.988 & 4.247 & 1.155 & $9.048 *$ \\
\hline $\begin{array}{l}\text { People feel frustrated when they need to use automation } \\
\text { technologies (r) }\end{array}$ & 4.34 & 1.538 & $27285.5^{*}$ & $17352 * *$ & 0.794 & 0.652 & 4.347 & 1.132 & 4.737 & 4.965 \\
\hline $\begin{array}{l}\text { People prefer to communicate with human employees rather than } \\
\text { with automation technologies (r) }\end{array}$ & 3.34 & 1.678 & 29764.5 & $16848 * *$ & 6.820 & 3.403 & $9.547 * *$ & 2.751 & 2.892 & 4.804 \\
\hline \multicolumn{11}{|l|}{ Innovative personality } \\
\hline $\begin{array}{l}\text { I consider myself to be creative and original in my thinking and } \\
\text { behaviour }\end{array}$ & 5.19 & 1.331 & 30300.5 & 19206 & 8.036 & $19.180 * * *$ & 2.819 & $12.898 * *$ & $10.120^{*}$ & 3.568 \\
\hline I seek out new ways to do things & 5.85 & 1.044 & $26491 * *$ & $15708 * * *$ & 1.302 & 3.521 & $9.444 * *$ & 4.354 & $14.793 * *$ & 1.935 \\
\hline I usually adopt new products before my friends do & 5.17 & 1.329 & $26908 *$ & $17787.5^{*}$ & 5.108 & $15.068 * *$ & $7.433^{*}$ & $10.989 *$ & $8.354 *$ & 0.042 \\
\hline Others see me as an innovative person & 4.77 & 1.304 & 29679.5 & 18435 & $11.073 *$ & 5.586 & $13.247 * * *$ & $16.346^{* * *}$ & $15.297 * *$ & 4.477 \\
\hline \multicolumn{11}{|l|}{ Social influence } \\
\hline $\begin{array}{l}\text { People who are important to me influence my opinion about } \\
\text { automation technologies }\end{array}$ & 3.87 & 1.657 & $26027 * *$ & 18689 & 5.493 & 5.817 & 0.311 & 0.801 & 1.456 & 1.253 \\
\hline $\begin{array}{l}\text { Media/social media influence my opinion about automation } \\
\text { technologies }\end{array}$ & 3.68 & 1.700 & 30037 & $14299.5 * * *$ & 2.977 & 1.970 & 1.000 & 3.576 & 1.276 & 3.173 \\
\hline I trust other people's opinions about automation technologies & 4.10 & 1.476 & $26284.5^{* *}$ & $16574.5^{* * *}$ & 2.325 & 0.636 & 4.174 & 2.999 & 2.115 & 0.500 \\
\hline $\begin{array}{l}\text { People who are acquainted to me influence my opinion about } \\
\text { automation technologies }\end{array}$ & 3.58 & 1.626 & 28763.5 & 18296.5 & 3.843 & 6.691 & 3.246 & 1.081 & 0.715 & 0.452 \\
\hline \multicolumn{11}{|l|}{ Technological skills } \\
\hline $\begin{array}{l}\text { It is not (will not be) hard for me to learn to use automation } \\
\text { technologies }\end{array}$ & 5.57 & 1.756 & 29014 & $15704.5 * * *$ & 5.382 & 8.517 & 0.804 & 6.167 & $11.338 * *$ & 1.348 \\
\hline
\end{tabular}




\begin{tabular}{|c|c|c|c|c|c|c|c|c|c|c|}
\hline \multirow[t]{2}{*}{ Statements } & \multirow[t]{2}{*}{ Mean } & \multirow{2}{*}{$\begin{array}{l}\text { St. } \\
\text { dev. }\end{array}$} & \multicolumn{2}{|c|}{ Mann-Whitney $U$-test } & \multicolumn{6}{|c|}{ Kruskal-Wallis $\chi 2$-test } \\
\hline & & & Gender & Cluster & Age & Education & Wellbeing & $\begin{array}{l}\text { Work } \\
\text { experience }\end{array}$ & Job level & $\begin{array}{l}\text { Place of } \\
\text { living }\end{array}$ \\
\hline $\begin{array}{l}\text { I am confident when I use a computer / computer applications / } \\
\text { software packages }\end{array}$ & 6.21 & 0.922 & $23161.5 * * *$ & $16804 * * *$ & 5.861 & 2.837 & $6.681 *$ & 2.645 & 4.929 & $7.958^{*}$ \\
\hline $\begin{array}{l}\text { I am confident when I use electronic devices around the house and } \\
\text { at work }\end{array}$ & 6.19 & 0.855 & $24436.5 * * *$ & $14633.5^{* * *}$ & 6.367 & 2.229 & $8.373^{*}$ & 3.191 & 2.655 & 3.509 \\
\hline I have the knowledge and skills to use automation technologies & 5.73 & 1.188 & $22267 * * *$ & $16816^{* * *}$ & 3.745 & 0.910 & $25.229 * * *$ & 4.466 & 6.092 & $10.857 * *$ \\
\hline \multicolumn{11}{|l|}{ Professionalism } \\
\hline I am (was) well prepared for my current (most recent) job & 5.87 & 1.135 & 30118.5 & $15909 * * *$ & 8.142 & $18.399 * * *$ & $15.165 * * *$ & $14.096^{* *}$ & $23.519 * * *$ & 2.654 \\
\hline I perform(ed) very well on my current (most recent) job & 6.18 & 0.801 & 29173 & $16906^{* *}$ & 5.100 & 3.402 & $9.017 *$ & 6.994 & $9.136 *$ & $6.947 *$ \\
\hline I stay(ed) up to date with the latest developments in my field & 5.66 & 1.192 & 28814.5 & $14977 * * *$ & 2.976 & $11.191 *$ & $14.845^{* * *}$ & 5.889 & $26.640 * * *$ & 3.941 \\
\hline \multicolumn{11}{|l|}{ Job automatability } \\
\hline $\begin{array}{l}\text { I think it would be easy to automate most of the activities I } \\
\text { currently perform(ed) on my job (r) }\end{array}$ & 4.44 & 1.919 & 30347.5 & $15502 * * *$ & 0.598 & 2.353 & 1.625 & 4.389 & 1.354 & 0.131 \\
\hline $\begin{array}{l}\text { Provided the opportunity, the managers of the company I currently } \\
\text { work(ed) for will substitute the human employees with automation } \\
\text { technologies (r) }\end{array}$ & 4.02 & 1.993 & $24929.5 * * *$ & $14964.5^{* * *}$ & 2.330 & 2.328 & $7.748^{*}$ & 0.800 & 4.161 & 1.324 \\
\hline $\begin{array}{l}\text { The company I currently work(ed) for uses (or plans to use) } \\
\text { actively automation technologies (r) }\end{array}$ & 3.46 & 1.883 & $26845^{*}$ & 18305 & 4.109 & 8.656 & $16.014 * * *$ & 0.565 & 0.984 & $16.875 * * *$ \\
\hline $\begin{array}{l}\text { The other companies in the sector use (or plan to use) actively } \\
\text { automation technologies (r) }\end{array}$ & 3.68 & 1.872 & $25484 * * *$ & 18474 & $11.012 *$ & 3.359 & $11.014 * *$ & 1.665 & 0.484 & 0.222 \\
\hline \multicolumn{11}{|l|}{ Fear } \\
\hline $\begin{array}{l}\text { I fear I might lose my current job due to automation technologies } \\
\text { within the next } 5 \text { years (r) }\end{array}$ & 6.00 & 1.205 & 29119 & $6205.5 * * *$ & $16.675^{* *}$ & 2.214 & 2.176 & 5.117 & 3.621 & 3.829 \\
\hline $\begin{array}{l}\text { I fear that, if I lose my current job due to automation, I will not be } \\
\text { able to find a new job in the same industry (r) }\end{array}$ & 5.80 & 1.411 & 28199 & $2964 * * *$ & $13.767 * *$ & 1.605 & 1.753 & $14.944 * *$ & $7.933^{*}$ & 1.567 \\
\hline $\begin{array}{l}\text { I fear that, if I lose my current job due to automation, I will not be } \\
\text { able to find a new job in another industry (r) }\end{array}$ & 5.90 & 1.299 & $25850 * *$ & $5110 * * *$ & $17.836^{* * *}$ & 1.364 & 0.801 & $16.453 * * *$ & 4.081 & 2.730 \\
\hline $\begin{array}{l}\text { I fear that if my salary is increased, my company will have good } \\
\text { reason to automate my job (r) }\end{array}$ & 5.59 & 1.456 & 29896.5 & $4612 * * *$ & $10.485 *$ & 1.336 & 2520 & 5.731 & 1.713 & 4.442 \\
\hline $\begin{array}{l}\text { I fear that the use of automation technologies will cause deskilling } \\
\text { of my current job and the company will hire someone with lower } \\
\text { education / skills (r) }\end{array}$ & 5.78 & 1.350 & 28574 & $5103.5 * * *$ & 2.286 & 0.569 & 2.582 & 2.127 & $8.458^{*}$ & $8.248^{*}$ \\
\hline $\begin{array}{l}\text { I fear that the use of automation technologies on my current job will } \\
\text { require knowledge and skills that I do not have (r) }\end{array}$ & 5.61 & 1.439 & 29210 & $5634.5^{* * * *}$ & 5.341 & 1.319 & 1.220 & 7.366 & 4.418 & $7.666^{*}$ \\
\hline
\end{tabular}

Notes: 1. Levels of significance: $* * * \mathrm{p}<0.001, * * \mathrm{p}<0.01, * \mathrm{p}<0.05 ; 2$. All statements measured on a 7 -point level of agreement scale (from 1-completely disagree to 7completely agree), excluding the statements on attitudes which are measured on a 7-point scale between from 1-extremely negative to 7-extremely positive; 3 . (r) - reverse coding; 4. Grouping variables: Gender (male/female), Cluster ('Confidents'/'Neutrals'), Age (18-30, 31-40, 41-50, 51-60, 61+), Education (Secondary / high school or lower, 
3-year Bachelor/Specialist, 4-year Bachelor, Master, Doctorate), Perceived economic wellbeing (Lower than average for the country, About the average for the country, Higher than the average for the country), Work experience (<10, 11-20, 21-30, 31+ years), Job level (No managerial or supervisory responsibilities, Supervisory role, Middle management, Top management), Place of living (Sofia, in Bulgaria outside Sofia, abroad). 
Table 3. Clusters' characteristics

\begin{tabular}{|c|c|c|c|c|}
\hline \multirow[t]{2}{*}{ Variable } & \multirow[t]{2}{*}{ Value } & \multicolumn{2}{|c|}{ Number of respondents } & \multirow[t]{2}{*}{ Chi-square } \\
\hline & & Confidents & Neutrals & \\
\hline \multirow[t]{3}{*}{ Gender } & Female & 168 & 44 & 0.525 \\
\hline & Male & 228 & 60 & \\
\hline & Prefer not to say & 2 & 0 & \\
\hline \multirow[t]{5}{*}{ Age } & $18-30$ & 112 & 22 & 9.441 \\
\hline & $31-40$ & 172 & 46 & \\
\hline & $41-50$ & 93 & 25 & \\
\hline & $51-60$ & 16 & 11 & \\
\hline & $61+$ & 5 & 0 & \\
\hline \multirow[t]{5}{*}{ Education } & Secondary / high school or lower & 48 & 17 & 2.607 \\
\hline & 3-year Bachelor/Specialist & 32 & 5 & \\
\hline & 4-year Bachelor & 96 & 24 & \\
\hline & Master & 200 & 51 & \\
\hline & Doctorate & 22 & 7 & \\
\hline \multirow{7}{*}{$\begin{array}{l}\text { Perceived } \\
\text { economic } \\
\text { wellbeing }\end{array}$} & Much less wealthy than the average for the country & 2 & 1 & $15.764 *$ \\
\hline & Less wealthy than the average for the country & 10 & 4 & \\
\hline & Slightly less wealthy than the average for the country & 18 & 13 & \\
\hline & About the average for the country & 111 & 36 & \\
\hline & Slightly more wealthy than the average for the country & 151 & 30 & \\
\hline & More wealthy than the average for the country & 92 & 15 & \\
\hline & Much more wealthy than the average for the country & 14 & 5 & \\
\hline \multirow[t]{7}{*}{ Place of living } & Sofia & 231 & 47 & 9.104 \\
\hline & Living in Bulgaria but outside Sofia, including: & 146 & 50 & \\
\hline & City with $100000-999999$ inhabitants & 94 & 31 & \\
\hline & Town with 10000 - 99999 inhabitants & 43 & 15 & \\
\hline & Town with less than 10000 inhabitants & 4 & 0 & \\
\hline & Village & 5 & 4 & \\
\hline & Bulgarian citizens who live abroad & 21 & 7 & \\
\hline Total & & 398 & 104 & \\
\hline
\end{tabular}

Note: * Significant at $\mathrm{p}<0.05$ 
Table 4. Factor analysis

\begin{tabular}{|c|c|c|c|c|c|c|c|}
\hline Factors & $\begin{array}{l}\text { Factor } \\
\text { loading }\end{array}$ & $\begin{array}{l}\text { Cronbach's } \\
\text { Alpha }\end{array}$ & $\begin{array}{l}\text { Composite } \\
\text { reliability }\end{array}$ & Eigenvalue & $\begin{array}{l}\text { Variance } \\
\text { explained }\end{array}$ & KMO & Bartlett \\
\hline FACTOR 1: Fear & & 0.868 & 0.928 & 3.641 & $60.69 \%$ & 0.888 & $1292.991 * * *$ \\
\hline $\begin{array}{l}\text { I fear I might lose my current job due to automation technologies within the next } 5 \\
\text { years }\end{array}$ & 0.793 & & & & & & \\
\hline $\begin{array}{l}\text { I fear that, if I lose my current job due to automation, I will not be able to find a new } \\
\text { job in the same industry }\end{array}$ & 0.840 & & & & & & \\
\hline $\begin{array}{l}\text { I fear that, if I lose my current job due to automation, I will not be able to find a new } \\
\text { job in another industry }\end{array}$ & 0.810 & & & & & & \\
\hline $\begin{array}{l}\text { I fear that if my salary is increased, my company will have good reason to automate } \\
\text { my job }\end{array}$ & 0.763 & & & & & & \\
\hline $\begin{array}{l}\text { I fear that the use of automation technologies will cause deskilling of my current job } \\
\text { and the company will hire someone with lower education / skills }\end{array}$ & 0.765 & & & & & & \\
\hline $\begin{array}{l}\text { I fear that the use of automation technologies on my current job will require } \\
\text { knowledge and skills that I do not have }\end{array}$ & 0.696 & & & & & & \\
\hline FACTOR 2: Perceived social benefits & & 0.878 & 0.932 & 4.115 & $58.792 \%$ & 0.892 & $1649.591 * * *$ \\
\hline $\begin{array}{l}\text { Automation technologies are (will be) responsible for many of the good things we } \\
\text { enjoy in life }\end{array}$ & 0.744 & & & & & & \\
\hline Automation technologies (will) improve our standard of living & 0.817 & & & & & & \\
\hline Automation technologies will bring us a bright future & 0.799 & & & & & & \\
\hline Life is (will be) easier with automation technologies & 0.800 & & & & & & \\
\hline Automation technologies (will) make our lives more convenient & 0.807 & & & & & & \\
\hline Automation technologies (will) eliminate a lot of tedious work for people & 0.622 & & & & & & \\
\hline Automation technologies (will) make people happier & 0.760 & & & & & & \\
\hline FACTOR 3: Advantages & & 0.855 & 0.926 & 3.584 & $59.725 \%$ & 0.873 & $1302.878 * * *$ \\
\hline $\begin{array}{l}\text { Automation technologies (will) provide more accurate information than human } \\
\text { employees }\end{array}$ & 0.721 & & & & & & \\
\hline Automation technologies (will) make fewer mistakes than human employees & 0.822 & & & & & & \\
\hline Automation technologies (will) perform faster than human employees & 0.801 & & & & & & \\
\hline Automation technologies are (will be) more reliable than human employees & 0.833 & & & & & & \\
\hline Automation technologies (will) have higher productivity than human employees & 0.821 & & & & & & \\
\hline Automation technologies are (will be) more cost effective than human employees & 0.616 & & & & & & \\
\hline FACTOR 4: Dehumanization & & 0.865 & 0.934 & 2.993 & $49.880 \%$ & 0.816 & $1047.169 * * *$ \\
\hline Automation technologies (will) hurt our human relationships in society & 0.835 & & & & & & \\
\hline $\begin{array}{l}\text { The overuse of automation technologies may be damaging and harmful to human } \\
\text { beings }\end{array}$ & 0.858 & & & & & & \\
\hline The overuse of automation technologies may be damaging and harmful to the & 0.855 & & & & & & \\
\hline
\end{tabular}

society as a whole 


\begin{tabular}{|c|c|c|c|c|c|c|c|}
\hline Factors & $\begin{array}{l}\text { Factor } \\
\text { loading }\end{array}$ & $\begin{array}{l}\text { Cronbach's } \\
\text { Alpha }\end{array}$ & $\begin{array}{l}\text { Composite } \\
\text { reliability }\end{array}$ & Eigenvalue & $\begin{array}{l}\text { Variance } \\
\text { explained }\end{array}$ & KMO & Bartlett \\
\hline Automation technologies will dehumanize the workplace & 0.788 & & & & & & \\
\hline FACTOR 5: Disadvantages & & 0.691 & 0.801 & 2.365 & $39.412 \%$ & 0.734 & $453.122 * * *$ \\
\hline $\begin{array}{l}\text { Automation technologies are (will be) able to deal with/operate only in standard } \\
\text { situations }\end{array}$ & 0.653 & & & & & & \\
\hline Automation technologies (will) lack the creativity of human employees & 0.545 & & & & & & \\
\hline $\begin{array}{l}\text { Automation technologies are (will be) difficult to operate by their intended users } \\
\text { (customers, employees) }\end{array}$ & 0.654 & & & & & & \\
\hline $\begin{array}{l}\text { Service provided by automation technologies are (will be) less interactive than } \\
\text { services provided by human employees }\end{array}$ & 0.692 & & & & & & \\
\hline People feel frustrated when they need to use automation technologies & 0.577 & & & & & & \\
\hline $\begin{array}{l}\text { People prefer to communicate with human employees rather than with automation } \\
\text { technologies }\end{array}$ & 0.633 & & & & & & \\
\hline FACTOR 6: Innovative personality & & 0.721 & 0.865 & 2.200 & $55.009 \%$ & 0.699 & $429.872 * * *$ \\
\hline I consider myself to be creative and original in my thinking and behaviour & 0.675 & & & & & & \\
\hline I seek out new ways to do things & 0.720 & & & & & & \\
\hline I usually adopt new products before my friends do & 0.734 & & & & & & \\
\hline Others see me as an innovative person & 0.829 & & & & & & \\
\hline FACTOR 7: Social influence & & 0.783 & 0.898 & 2.440 & $61.009 \%$ & 0.756 & $595.453 * * *$ \\
\hline $\begin{array}{l}\text { People who are important to me influence my opinion about automation } \\
\text { technologies }\end{array}$ & 0.833 & & & & & & \\
\hline Media/social media influence my opinion about automation technologies & 0.686 & & & & & & \\
\hline I trust other people's opinions about automation technologies & 0.748 & & & & & & \\
\hline $\begin{array}{l}\text { People who are acquainted to me influence my opinion about automation } \\
\text { technologies }\end{array}$ & 0.846 & & & & & & \\
\hline FACTOR 8: Technological skills & & 0.800 & 0.917 & 2.352 & $58.791 \%$ & 0.735 & $590.292 * * *$ \\
\hline I am confident when I use a computer / computer applications / software packages & 0.858 & & & & & & \\
\hline I am confident when I use electronic devices around the house and at work & 0.857 & & & & & & \\
\hline I have the knowledge and skills to use automation technologies & 0.799 & & & & & & \\
\hline FACTOR 9: Professionalism & & 0.738 & 0.899 & 1.997 & $66.577 \%$ & 0.680 & $352.629 * * *$ \\
\hline I am (was) well prepared for my current (most recent) job & 0.847 & & & & & & \\
\hline I perform(ed) very well on my current (most recent) job & 0.786 & & & & & & \\
\hline I stay(ed) up to date with the latest developments in my field & 0.814 & & & & & & \\
\hline FACTOR 10: Job automatability & & 0.702 & 0.859 & 2.147 & $53.686 \%$ & 0.696 & $408.001 * * *$ \\
\hline $\begin{array}{l}\text { I think it would be easy to automate most of the activities I currently perform(ed) on } \\
\text { my job }\end{array}$ & 0.575 & & & & & & \\
\hline $\begin{array}{l}\text { Provided the opportunity, the managers of the company I currently work(ed) for will } \\
\text { substitute the human employees with automation technologies }\end{array}$ & 0.694 & & & & & & \\
\hline
\end{tabular}




\begin{tabular}{|c|c|c|c|c|c|c|c|}
\hline Factors & $\begin{array}{l}\text { Factor } \\
\text { loading }\end{array}$ & $\begin{array}{l}\text { Cronbach's } \\
\text { Alpha }\end{array}$ & $\begin{array}{l}\text { Composite } \\
\text { reliability }\end{array}$ & Eigenvalue & $\begin{array}{l}\text { Variance } \\
\text { explained }\end{array}$ & KMO & Bartlett \\
\hline $\begin{array}{l}\text { The company I currently work(ed) for uses (or plans to use) actively automation } \\
\text { technologies }\end{array}$ & 0.801 & & & & & & \\
\hline $\begin{array}{l}\text { The other companies in the sector use (or plan to use) actively automation } \\
\text { technologies }\end{array}$ & 0.833 & & & & & & \\
\hline
\end{tabular}


Table 5. Discriminant validity matrix

\begin{tabular}{|c|c|c|c|c|c|c|c|c|c|c|}
\hline Factors & Fear & $\begin{array}{l}\text { Perceived } \\
\text { social } \\
\text { benefits }\end{array}$ & Advantages & Dehumanisation & Disadvantages & $\begin{array}{l}\text { Innovative } \\
\text { personality }\end{array}$ & $\begin{array}{l}\text { Social } \\
\text { influence }\end{array}$ & $\begin{array}{l}\text { Technological } \\
\text { skills }\end{array}$ & Professionalism & $\begin{array}{l}\text { Job } \\
\text { automatability }\end{array}$ \\
\hline Fear & 0.7790 & & & & & & & & & \\
\hline $\begin{array}{l}\text { Perceived social } \\
\text { benefits }\end{array}$ & $0.300 * * *$ & 0.7668 & & & & & & & & \\
\hline Advantages & $0.238 * * *$ & $0.679 * * *$ & 0.7728 & & & & & & & \\
\hline Dehumanisation & $0.369 * * *$ & $0.525 * * *$ & $0.342 * * *$ & 0.7063 & & & & & & \\
\hline Disadvantages & $0.255^{* * *}$ & $0.343 * * *$ & $0.341 * * *$ & $0.574 * * *$ & 0.6278 & & & & & \\
\hline $\begin{array}{l}\text { Innovative } \\
\text { personality }\end{array}$ & $0.176^{* * *}$ & $0.359 * * *$ & $0.275^{* * *}$ & $0.129 * *$ & 0.077 & 0.7417 & & & & \\
\hline Social influence & $-0.221 * * *$ & 0.038 & -0.034 & -0.076 & $-0.100 *$ & 0.024 & 0.7811 & & & \\
\hline Technological skills & $0.238 * * *$ & $0.428 * * *$ & $0.368 * * *$ & $0.200 * * *$ & $0.116^{* *}$ & $0.521 * * *$ & $-0.097 *$ & 0.7668 & & \\
\hline Professionalism & $0.261 * * *$ & $0.288 * * *$ & $0.280 * * *$ & $0.107 *$ & 0.083 & $0.432 * * *$ & -0.072 & $0.412 * * *$ & 0.8159 & \\
\hline Job automatability & $0.252 * * *$ & $-0.150 * * *$ & $-0.116^{* *}$ & 0.035 & -0.025 & $-0.239 * * *$ & $-0.184 * * *$ & $-0.178 * * *$ & $-0.097 *$ & 0.7327 \\
\hline
\end{tabular}

Notes: 1. The diagonal cells indicate the square root of AVE. Bivariate Pearson correlations in the cells below the diagonal. 2 . Levels of significance: $* * *$ p $<0.001$, $* *$

$\mathrm{p}<0.01, * \mathrm{p}<0.05$ 
Table 6. Regression analysis results

\begin{tabular}{|c|c|c|c|c|c|c|c|c|c|c|c|c|c|c|c|c|}
\hline \multirow{3}{*}{$\begin{array}{l}\text { Independent variables } \\
\text { Dependent variable: Fear }(r)\end{array}$} & \multicolumn{8}{|c|}{ Model 1} & \multicolumn{8}{|l|}{ Model 2} \\
\hline & \multicolumn{2}{|c|}{$\begin{array}{l}\text { Unstandardized } \\
\text { Coefficients }\end{array}$} & \multirow{2}{*}{$\begin{array}{l}\text { Standardized } \\
\text { Coefficients } \\
\text { Beta }\end{array}$} & \multirow[t]{2}{*}{ t } & \multicolumn{2}{|c|}{$\begin{array}{l}\text { 95\% Confidence } \\
\text { interval for B }\end{array}$} & \multirow{2}{*}{$\begin{array}{l}\text { Collinearity } \\
\text { Statistics } \\
\text { Tolerance }\end{array}$} & \multirow{2}{*}{$\begin{array}{l}\mathbf{y} \\
\text { VIF }\end{array}$} & \multicolumn{2}{|c|}{$\begin{array}{l}\text { Unstandardized } \\
\text { Coefficients }\end{array}$} & \multirow{2}{*}{$\begin{array}{l}\text { Standardized } \\
\text { Coefficients } \\
\text { Beta }\end{array}$} & \multirow[t]{2}{*}{$\mathbf{t}$} & \multicolumn{2}{|c|}{$\begin{array}{l}\text { 95\% Confidence } \\
\text { interval for B }\end{array}$} & \multicolumn{2}{|c|}{$\begin{array}{l}\text { Collinearity } \\
\text { Statistics }\end{array}$} \\
\hline & B & $\begin{array}{l}\text { Std. } \\
\text { Error }\end{array}$ & & & $\begin{array}{l}\text { Lower } \\
\text { bound }\end{array}$ & $\begin{array}{l}\text { Upper } \\
\text { bound }\end{array}$ & & & B & $\begin{array}{l}\text { Std. } \\
\text { Error }\end{array}$ & & & $\begin{array}{l}\text { Lower } \\
\text { bound }\end{array}$ & $\begin{array}{l}\text { Upper } \\
\text { bound }\end{array}$ & Tolerance & VIF \\
\hline (Constant) & -0.001 & 0.038 & & -0.022 & -0.075 & 0.073 & & & 0.258 & 0.247 & & 1.045 & -0.227 & 0.744 & & \\
\hline Factor: Perceived social benefits & 0.102 & 0.060 & 0.102 & 1.685 & -0.017 & 0.220 & 0.392 & 2.549 & 0.091 & 0.061 & 0.091 & 1.488 & -0.029 & 0.211 & 0.378 & 2.642 \\
\hline Factor: Dehumanisation (r) & 0.218 & 0.052 & 0.218 & $4.196^{* * * *}$ & 0.116 & 0.320 & 0.528 & 1.893 & 0.211 & 0.052 & 0.210 & $4.023 * * *$ & 0.108 & 0.314 & 0.518 & 1.932 \\
\hline Factor: Advantages & 0.012 & 0.053 & 0.012 & 0.232 & -0.092 & 0.117 & 0.506 & 1.977 & -0.005 & 0.054 & -0.005 & -0.091 & -0.111 & 0.101 & 0.482 & 2.074 \\
\hline Factor: Disadvantages (r) & 0.058 & 0.047 & 0.058 & 1.226 & -0.035 & 0.151 & 0.636 & 1.572 & 0.069 & 0.047 & 0.069 & 1.458 & -0.024 & 0.162 & 0.628 & 1.592 \\
\hline Factor: Innovative personality & 0.066 & 0.047 & 0.066 & 1.402 & -0.027 & 0.159 & 0.636 & 1.572 & 0.086 & 0.048 & 0.086 & 1.786 & -0.009 & 0.181 & 0.607 & 1.646 \\
\hline Factor: Social influence & -0.133 & 0.039 & -0.133 & $-3.380 * * *$ & -0.210 & -0.056 & 0.921 & 1.086 & -0.124 & 0.040 & -0.124 & $-3.130 * *$ & -0.202 & -0.046 & 0.896 & 1.116 \\
\hline Factor: Technological skills & 0.079 & 0.048 & 0.079 & 1.631 & -0.016 & 0.173 & 0.614 & 1.629 & 0.061 & 0.049 & 0.061 & 1.255 & -0.034 & 0.156 & 0.597 & 1.674 \\
\hline Factor: Professionalism & 0.157 & 0.044 & 0.157 & $3.591 * * *$ & 0.071 & 0.242 & 0.748 & 1.337 & 0.177 & 0.045 & 0.177 & $3.884 * * *$ & 0.087 & 0.266 & 0.684 & 1.462 \\
\hline Factor: Job automatability (r) & 0.284 & 0.040 & 0.284 & $7.083 * * *$ & 0.205 & 0.362 & 0.888 & 1.126 & 0.291 & 0.040 & 0.291 & $7.203 * * *$ & 0.211 & 0.370 & 0.868 & 1.152 \\
\hline Work experience & & & & & & & & & -0.005 & 0.009 & -0.041 & -0.568 & -0.022 & 0.012 & 0.273 & 3.664 \\
\hline Job level & & & & & & & & & 0.027 & 0.038 & 0.029 & 0.707 & -0.047 & 0.101 & 0.826 & 1.211 \\
\hline Years on the job & & & & & & & & & -0.014 & 0.013 & -0.048 & -1.106 & -0.039 & 0.011 & 0.750 & 1.332 \\
\hline Education & & & & & & & & & 0.016 & 0.036 & 0.018 & 0.458 & -0.054 & 0.087 & 0.876 & 1.141 \\
\hline Age & & & & & & & & & -0.009 & 0.008 & -0.079 & -1.099 & -0.024 & 0.007 & 0.276 & 3.622 \\
\hline Gender & & & & & & & & & 0.068 & 0.078 & 0.035 & 0.879 & -0.085 & 0.221 & 0.874 & 1.144 \\
\hline $\mathrm{R}$ & 0.549 & & & & & & & & 0.564 & & & & & & & \\
\hline R Square & 0.301 & & & & & & & & 0.318 & & & & & & & \\
\hline Adjusted R Square & 0.288 & & & & & & & & 0.297 & & & & & & & \\
\hline F-statistic & $23.492 * * *$ & & & & & & & & $14.993 * * *$ & & & & & & & \\
\hline Standard Error of the Estimate & 0.8445 & & & & & & & & 0.8400 & & & & & & & \\
\hline
\end{tabular}




\begin{tabular}{|c|c|c|c|c|c|c|c|c|c|c|}
\hline \multirow[t]{2}{*}{ Statements } & \multirow[t]{2}{*}{ Mean } & \multirow{2}{*}{$\begin{array}{l}\text { Standard } \\
\text { deviation }\end{array}$} & \multicolumn{2}{|c|}{ Mann-Whitney $U$-test } & \multicolumn{6}{|c|}{ Kruskal-Wallis $\chi 2$-test } \\
\hline & & & Gender & Cluster & Age & Education & Wellbeing & $\begin{array}{l}\text { Work } \\
\text { experience }\end{array}$ & Job level & $\begin{array}{l}\text { Place of } \\
\text { living }\end{array}$ \\
\hline \multicolumn{11}{|l|}{ Individual solutions: } \\
\hline $\begin{array}{l}\text { I will try to improve my qualification in order to perform on my } \\
\text { current job better than the automation technologies }\end{array}$ & 5.43 & 1.528 & $26361.5 * *$ & $17695^{*}$ & 0.816 & 4.383 & 5.020 & 3.824 & 3.212 & 0.121 \\
\hline $\begin{array}{l}\text { I will try to learn how to use automation technology to be more } \\
\text { productive on my current job }\end{array}$ & 6.01 & 1.140 & 29291 & $15781 * * *$ & 5.574 & 1.678 & 3.680 & 0.998 & 2.069 & 1.778 \\
\hline $\begin{array}{l}\text { I will look for a job in the industry I currently work in that is not } \\
\text { going to be automated soon }\end{array}$ & 3.80 & 1.821 & 29309.5 & $16134 * * *$ & 7.069 & $16.070 * *$ & 0.679 & 6.759 & $12.475^{* *}$ & 5.432 \\
\hline $\begin{array}{l}\text { I will look for a job in a different industry that in not going to be } \\
\text { automated soon }\end{array}$ & 3.44 & 1.808 & 29585.5 & $14329 * * *$ & 1.130 & $11.177 *$ & 0.519 & 3.564 & $8.687^{*}$ & $7.499 *$ \\
\hline I will not undertake anything & 2.29 & 1.552 & 28900.5 & $16448 * * *$ & 9.405 & $14.419 * *$ & 2.855 & 6.660 & 0.730 & 4.040 \\
\hline \multicolumn{11}{|l|}{ Corporate solutions: } \\
\hline $\begin{array}{l}\text { Producers of automation technologies should evaluate and publicly } \\
\text { announce the impact of automation technologies on jobs }\end{array}$ & 4.49 & 1.842 & $25582.5^{* *}$ & $16612.5 * *$ & 6.858 & 5.139 & $12.794 * *$ & 6.269 & 3.206 & 5.629 \\
\hline $\begin{array}{l}\text { Companies that use automation technologies should evaluate and } \\
\text { publicly announce the impact of automation technologies on jobs } \\
\text { before these technologies are being adopted by them }\end{array}$ & 4.48 & 1.836 & $25411.5 * * *$ & $16479.5 * * *$ & 4.726 & 3.337 & $14.786 * * *$ & 4.967 & 2.481 & 5.886 \\
\hline $\begin{array}{l}\text { Companies should introduce work sharing and reduced working } \\
\text { hours for employees }\end{array}$ & 4.69 & 1.613 & 29240.5 & 19812 & 5.062 & 5.064 & 0.770 & 2.874 & 2.034 & 0.862 \\
\hline $\begin{array}{l}\text { Companies should provide free requalification for displaced } \\
\text { employees }\end{array}$ & 4.99 & 1.721 & $24874.5^{* * *}$ & $16118 * * *$ & 7.238 & 5.239 & 4.882 & 3.134 & 5.601 & 1.042 \\
\hline $\begin{array}{l}\text { Consumers should boycott companies that substitute their } \\
\text { employees with automation technologies }\end{array}$ & 2.20 & 1.409 & $24820 * * *$ & 13313.5 & 4.558 & 1.834 & $10.564 * *$ & 1.117 & 4.535 & $13.390 * * *$ \\
\hline \multicolumn{11}{|l|}{ Social solutions: } \\
\hline $\begin{array}{l}\text { The government should provide free education to everyone to } \\
\text { improve their qualification }\end{array}$ & 4.71 & 1.804 & 29141.5 & 19032 & 2.774 & 5.745 & $10.217 * *$ & 6.267 & 1.487 & 1.664 \\
\hline $\begin{array}{l}\text { The government should provide free education only to those who } \\
\text { have lost their jobs due to automation technologies }\end{array}$ & 3.19 & 1.832 & $27132 *$ & $17361 * *$ & 1.513 & $16.784 * *$ & 0.576 & 6.636 & 0.626 & $9.300 * *$ \\
\hline $\begin{array}{l}\text { The government should provide basic income to every citizen of } \\
\text { the country }\end{array}$ & 3.07 & 2.005 & 30126 & 17864* & 6.243 & 6.499 & 5.728 & 1.533 & $8.707 *$ & $6.103 *$ \\
\hline $\begin{array}{l}\text { The government should provide basic income only to those who } \\
\text { have lost their jobs due to automation technologies }\end{array}$ & 3.07 & 1.769 & $22231.5 * * *$ & $14730 * * *$ & 5.635 & 7.650 & 5.571 & 4.000 & 4.163 & 4.664 \\
\hline The government should tax automation technologies & 3.14 & 1.907 & $25301.5^{* * *}$ & $14360 * * *$ & 7.811 & 0.589 & $11.134 * *$ & 4.743 & 1.780 & 4.079 \\
\hline The government should hire everyone who has lost his/her job due & 2.53 & 1.669 & $23604.5^{* * *}$ & $15097.5 * * *$ & 3.764 & 3.382 & 5.773 & 0.934 & 2.506 & $11.257 * *$ \\
\hline
\end{tabular}


The government should provide financial incentives to companies

$27325.5^{*}$

18841.5

$3.609 \quad 4.380$

5.260

5.967 Notes: 1. Levels of significance: $* * * \mathrm{p}<0.001, * * \mathrm{p}<0.01,{ }^{*} \mathrm{p}<0.05 ; 2$. All statements measured on a 7-point level of agreement scale (from 1-completely disagree to 7-
completely agree). 3. Grouping variables: Gender (male/female), Cluster ('Confidents' / 'Neutrals'), Age (18-30, 31-40, 41-50, 51-60, 61+), Education (Secondary / high school

or lower, 3-year Bachelor/Specialist, 4-year Bachelor, Master, Doctorate), Perceived economic wellbeing (Lower than average for the country, About the average for the country, Higher than the average for the country), Work experience (<10, 11-20, 21-30, 31+ years), Job level (No managerial or supervisory responsibilities, Supervisory role, Middle management, Top management), Place of living (Sofia, in Bulgaria outside Sofia, abroad). 
Table 8. Exploratory factor analysis from the solutions items

\begin{tabular}{|c|c|c|c|c|c|}
\hline Factors & $\begin{array}{l}\text { Factor } \\
\text { loading }\end{array}$ & $\begin{array}{l}\text { Cronbach's } \\
\text { Alpha }\end{array}$ & $\begin{array}{l}\text { Composite } \\
\text { reliability }\end{array}$ & Eigenvalue & $\begin{array}{l}\text { Variance } \\
\text { explained }\end{array}$ \\
\hline FACTOR 1: Economic solutions & & 0.813 & 0.867 & 4.704 & $27.671 \%$ \\
\hline $\begin{array}{l}\text { Producers of automation technologies should evaluate and publicly announce the impact of } \\
\text { automation technologies on jobs before these technologies are being introduced by them }\end{array}$ & 0.809 & & & & \\
\hline $\begin{array}{l}\text { Companies that use automation technologies should evaluate and publicly announce the impact of } \\
\text { automation technologies on jobs before these technologies are being adopted by them }\end{array}$ & 0.793 & & & & \\
\hline $\begin{array}{l}\text { The government should provide financial incentives to companies to use human employees rather } \\
\text { than automation technologies }\end{array}$ & 0.703 & & & & \\
\hline The government should tax automation technologies & 0.629 & & & & \\
\hline Consumers should boycott companies that substitute their employees with automation technologies & 0.612 & & & & \\
\hline FACTOR 2: Targeted solutions & & 0.647 & 0.641 & 1.738 & $10.224 \%$ \\
\hline The government should impose strict birth control on population & 0.622 & & & & \\
\hline $\begin{array}{l}\text { The government should provide free education only to those who have lost their jobs due to } \\
\text { automation technologies }\end{array}$ & 0.614 & & & & \\
\hline The government should hire everyone who has lost his/her job due to automation technologies & 0.533 & & & & \\
\hline $\begin{array}{l}\text { The government should provide basic income only to those who have lost their jobs due to } \\
\text { automation technologies }\end{array}$ & 0.520 & & & & \\
\hline FACTOR 3: Socialist solutions & & 0.622 & 0.726 & 1.476 & $8.682 \%$ \\
\hline Companies should introduce work sharing and reduced working hours for employees & 0.719 & & & & \\
\hline The government should provide free education to everyone to improve their qualification & 0.640 & & & & \\
\hline The government should provide basic income to every citizen of the country & 0.605 & & & & \\
\hline Companies should provide free requalification for displaced employees & 0.519 & & & & \\
\hline FACTOR 4: Escapism & & 0.771 & 0.922 & 1.257 & $7.394 \%$ \\
\hline I will look for a job in a different industry that is not going to be automated soon & 0.887 & & & & \\
\hline I will look for a job in the industry I currently work in that is not going to be automated soon & 0.878 & & & & \\
\hline FACTOR 5: Self-improvement & & 0.592 & 0.878 & 1.143 & $6.724 \%$ \\
\hline $\begin{array}{l}\text { I will try to improve my qualification in order to perform on my current job better than the } \\
\text { automation technology }\end{array}$ & 0.855 & & & & \\
\hline I will try to learn how to use the automation technology to be more productive on my current job & 0.818 & & & & \\
\hline Total variance explained & & & & & $60.695 \%$ \\
\hline
\end{tabular}


Table 9. Support for the research hypotheses

\section{GROUP 1: Automation fears}

1. General perceptions of automation technologies.

H1.1. Perceived social benefits of automation technologies are negatively related to the fear of automation

H1.2. Perceived dehumanisation effect of automation technologies is positively related to the fear of

Not supported

automation

2. Characteristics of automation technologies as production factors compared to human employees:

H2.1. Perceived advantages of automation technologies compared to human employees are positively related to the fear of automation technologies

H2.2. Perceived disadvantages of automation technologies compared to human employees are negatively Not supported

related to the fear of automation technologies

3. Self-perception of human employees.

H3.1. People who consider themselves as innovative are less afraid of losing their jobs to automation

technologies

H3.2. People who consider themselves as professionals are less afraid of losing their jobs to automation technologies

H3.3. People with higher technological skills are afraid of losing their jobs to automation technologies

4. Demographic characteristics:

H4.1. Men have higher fear of automation

H4.2. Younger people are less afraid of losing their jobs to automation technologies

H4.3. More educated people are less afraid of losing their jobs to automation technologies

H4.4. Perceived economic wellbeing is negatively associated to the fear of automation

Supported

ot supported

Supported

Not supported

technologies

5. Job characteristics.

H5.1. Job automatability is positively related to automation fear

Not supported

Partially

supported

Supported by the Kruskal-Wallis $\chi 2$ test (Table 2)

Not supported

but not by the regression analysis (Table 6) when

Not supported

all variables are taken into consideration

Not supported

H5.2. Lower job positions are associated to higher fear of automation

Supported

6. Work experience:

H6.1. Longer work experience is negatively associated to automation fear

Not supported

H6.2. Number of years on a particular job position is negatively associated to automation fear

7. Social influence:

H7. Automation fears are shaped by peer pressure

GROUP 2: Solutions to automation fears

Not supported Work experience increases fear

Not supported

8. Demographic characteristics:

Supported 
H8.1. Gender influences the support for the solutions to automation fears

H8.2. Age influences the support for the solutions to automation fears

H8.3. Education influences the support for the solutions to automation fears

H8.4. Perceived economic wellbeing influences the support for the solutions to automation fears

H8.5. Place of living influences the support for the solutions to automation fears

9. Job level:

H9. Job level influences the support for the solutions to automation fears

10. Work experience:

H10. Work experience influences the support for the solutions to automation fears
Supported

Not supported

Not supported

Partially

supported

Partially

supported
Significant differences in the support for 1 individual, 4 corporate and 6 social solutions

Significant differences in the support for 3

corporate and 3 social solution

Significant differences in the support for 1 individual, 1 corporate and 5 social solutions 
Appendix 1. Sources of scale items

\section{Perceived social benefits}

Automation technologies are (will be) responsible for many of the good things we enjoy in life

Automation technologies (will) improve our standard of living

(2017) and expanded by the

Automation technologies will bring us a bright future

Life is (will be) easier with automation technologies

Automation technologies (will) make our lives more convenient

Automation technologies (will) eliminate a lot of tedious work for people

Automation technologies (will) make people happier

\section{Dehumanisation}

Automation technologies (will) hurt our human relationships in society (r)

In the future, automation technologies will dominate society (r)

The overuse of automation technologies may be damaging and harmful to human beings ( $r$ )

authors

The overuse of automation technologies may be damaging and harmful to the society as a whole (r)

Automation technologies (will) dehumanize the workplace (r)

Automation technologies (will) lead to deskilling of jobs (r)

\section{Advantages}

Automation technologies (will) provide more accurate information than human employees

Automation technologies (will) make fewer mistakes than human employees

Automation technologies (will) perform faster than human employees

Automation technologies are (will be) more reliable than human employees

Automation technologies (will) have higher productivity than human employees

Automation technologies are (will be) more cost effective than human employees

\section{Disadvantages}

Automation technologies are (will be) able to deal with/operate only in standard situations (r)

Automation technologies (will) lack the creativity of human employees (r)

Automation technologies are (will be) difficult to operate by their intended users (customers, employees) (r)

Tussyadiah, Zach \& Wang (2017) and expanded by the authors

People feel frustrated when they need to use automation technologies (r)

People prefer to communicate with human employees rather than with automation technologies (r)

\section{Innovative personality}

I consider myself to be creative and original in my thinking and behaviour

I seek out new ways to do things

I usually adopt new products before my friends do

Ivanov, Webster \& Garenko (2018) and expanded by the authors

Ivanov, Webster \& Garenko (2018) and expanded by the authors

Others see me as an innovative person

Social influence 
People who are important to me influence my opinion about automation technologies

Media/social media influence my opinion about automation technologies

I trust other people's opinions about automation technologies

People who are acquainted to me influence my opinion about automation technologies

\section{Technological skills}

It is not (will not be) hard for me to learn to use automation technologies

I am confident when I use a computer / computer applications / software packages

I am confident when I use electronic devices around the house and at work

I have the knowledge and skills to use automation technologies

Venkatesh, Thong \& Xu

(2012), Chen \& Huang

(2016) and expanded by the

authors

Developed by the authors on

basis of the Effort

Expectancy scale by

Venkatesh, Thong \& Xu

Professionalism
I am (was) well prepared for my current (most recent) job

I perform(ed) very well on my current (most recent) job

I stay(ed) up to date with the latest developments in my field

\section{Job automatability}

I think it would be easy to automate most of the activities I currently perform(ed) on my job (r)

Developed by the authors

Provided the opportunity, the managers of the company I currently work(ed) for will substitute the

The company I currently work(ed) for uses (or plans to use) actively automation technologies (r)

The other companies in the sector use (or plan to use) actively automation technologies (r)

\section{Fear}

I fear I might lose my current job due to automation technologies within the next 5 years (r)

I fear that, if I lose my current job due to automation, I will not be able to find a new job in the same industry (r)

I fear that, if I lose my current job due to automation, I will not be able to find a new job in another industry (r)

I fear that if my salary is increased, my company will have good reason to automate my job (r)

I fear that the use of automation technologies will cause deskilling of my current job and the company will hire someone with lower education / skills (r)

I fear that the use of automation technologies on my current job will require knowledge and skills that I do not have (r) 